\title{
Lietuvos žvalgybos sistema
}

\begin{abstract}
Šiame straipsnyje analizuojama Lietuvos žvalgybos sistema, kaip ji atitinka kitu šaliu praktiką, žvalgybos tarnybų ir politikų santykis. Straipsnyje analizuojama Valstybės saugumo departamento (VSD) ir Antrojo operatyviniu tarnybu departamento (AOTD) prie Krašto apsaugos ministerijos veikla, ju teikiama produkcija ir informacijos rinkimo galimybès. Straipsnyje daroma išvada, kad Lietuvos žvalgybos sistema iš esmès atitinka Vakarų šalių modelius, tačiau funkcinis veiklos sričių pasidalinimas, darbo kultūra ir kiti faktoriai smarkiai riboja žvalgybos tarnybų darbą.
\end{abstract}

\section{Ivadas}

Žvalgyba yra dažnas visuomenės ir politikų diskusijų objektas. Žvalgybos tarnybos ir ju veiksmai dažnai tampa ịvairių konspiracijos teoriju pagrindu, o pačiu tarnybu veikla - įvairių nesusipratimų ir spekuliacijų objektu. İsivaizduojamos žvalgybos tarnybu galios ir ryšiai su politikais, verslininkais ar kultūros elitu dažnai tampa žiniasklaidos dèmesio objektu visame pasaulyje, įskaitant ir Lietuvą.

Žvalgybos teorija ir žvalgybos tarnybu veiklos analizė yra populiarus mokslininkų tyrimo objektas Vakarų šalyse. Šiai temai skiriamos knygos leidžiamos dideliu tiražu, o Vakaru universitetuose bazinis žvalgybos kursas tampa universitetinio išsilavinimo dalimi. Žvalgybos darbo metodų pritaikymas plečiasi, ji vis tampriau siejama su verslo praktika, ir nebėra suprantama kaip strateginių ar saugumo studiju atstovu monopolis.

Nors žvalgybos geografija plečiasi, daugelis publikacijų žvalgybos tema yra skiriamos anglosaksišku šalių auditorijai, o žvalgybos tarnybų veikla yra aptariama tik JAV, Rusijos ir Didžiosios Britanijos žvalgybos tarnybų pavyzdžiais. Mažų šalių žvalgybos tarnybos nusipelno nedidelio akademijos bendruomenès dèmesio, o rašančių šių šaliu atstovų taip pat tèra tik vienetai.

Nedidelis dėmesys skiriamas mažų valstybių žvalgybos tarnyboms prisideda prie įvairių nesusipratimų šiame svarbiame valstybẻs saugumo politikos sektoriuje. Mažoms valstybėms nacionalinio saugumo klausimai yra ypatingai svarbūs, valstybės išlikimas joms nèra tik teorinis klausimas. Todèl žvalgybos tarnybos jose dažnai atlieka gana ypatingą vaidmeni, ir yra labiau susietos su

\footnotetext{
* Dr. Vaidotas Urbelis - Lietuvos karo akademijos Politikos moklsų katedros dėstytojas. Adresas: Šilo 5a, 10332 Vilnius; tel. 8-5-2103569; el. paštas: vaidurb@gmail.com.
} 
politika nei didesnėse valstybėse. Kaip Edvardas Lucasas pastebėjo, „sunku būtų rytų Europoje surasti valstybę, kur žvalgyba ir saugumo agentūros būtų depolitizuotos ir nekontraversiškos “1. Lietuva yra puikus pavyzdys šalies, kur žvalgybos tarnybos tapo integralia šalies politinio gyvenimo dalimi. Jų įtaka jaučiama daugelyje sričių - nuo užsienio politikos klausimų iki šalies prezidento nušalinimo procedūros. Pastaroji sukèlè didelius debatus apie žvalgybos, politikos ir teisėsaugos institucijų santykį.

Visuomenès susidomèjimas dar labiau išaugo po Valstybės saugumo departamento (VSD) pareigūno Vytauto Pociūno žūties. Nors buvo teigiama, kad jis iškrito pro viešbučio langą, nemaža dalis visuomenès tiki žmogžudystès versija. Parlamentas atliko tyrimą, kurio išvados buvo labai nepalankios VSD. Parlamentinis tyrimas bandè parodyti, kad Lietuvos žvalgybos sistemos struktūros ir procedūros turi didžiulių trūkumų, kuriuos būtina šalinti.

Šis straipsnis - tai pirmas bandymas aprašyti ir suprasti Lietuvos žvalgybos sistemą, supažindinti skaitytojus su jos stipriomis ir silpnosiomis pusemis. Šiame straipsnyje parodoma, kaip Lietuvos žvalgybos tarnybos veikia saugumo ir gynybos politiką, kaip žvalgybos tarnybos atrodo tarp kitų pasaulio žvalgybos tarnybų.

Kiekviena šalis yra skirtinga, jos žvalgybos tarnybos taip pat skiriasi. Lietuvos žvalgybos sistema atspindi tiek šalies istorinę praeiti, tiek bandymus susidoroti su naujomis grèsmėmis. Du svarbiausi veikèjai - Valstybès saugumo departamentas ir Antrasis operatyviniu tarnybų departamentas (AOTD) prie Krašto apsaugos ministerijos per savo plètros istoriją patyrė daug permainų ir išbandymu, o jų vaidmuo ir struktūra iki šiol tebẻra politikų svarstymų objektas. Šiame straipsnyje bandoma žiūrèti ì žvalgybos tarnybą plačiąja prasme, pristatant ne tik ju veiklą, bet ir jų santykius su kitomis institucijomis, kurios dalyvauja ir kuria Lietuvos nacionalinę saugumo politiką.

Šis straipsnis Lietuvos žvalgybos sistemą analizuos daugiausia iš praktinès pusès. Tiesa, informacijos trūkumas lieka ribojančiu veiksniu, jis neleidžia plačiau pažvelgti į žvalgybinès informacijos rinkimo ar analizės pajėgumus Lietuvoje. Dèl šių priežasčių straipsnyje nieko nerašoma apie agentūrinę veiklą ar Lietuvos žvalgybos gebẻjimus klausyti užsienio piliečių mobilių telefonų pokalbių. Tokie duomenys nėra pasiekiami plačiajai visuomenei, o šių duomenų skleidimas net užtrauktų baudžiamąą atsakomybę.

Straipsnis susideda iš trijų dalių. Pirmojoje trumpai pristatoma pasiekiama literatūra apie žvalgybą Lietuvoje. Antrojoje apžvelgiama Lietuvos žvalgybos institucinè sąranga, pavaldumo santykiai, žvalgybos tarnybų koordinacijos mechanizmas. Trečioji darbo dalis pristato žvalgybos ciklo igyvendinamą Lietuvoje, t. y. kaip vyksta žvalgybinès informacijos rengimas nuo „užsakymo“ suformulavimo iki „produkto“ parengimo. Straipsnio išvadose pateikiami pasiūlymai ir komentarai, kas turètų būti pakeista, gerinant Lietuvos žvalgybos tarnybų darbą, kokie laukia svarbiausi ateities iššūkiai ir problemos.

Lucas E., ,State Insecurity“, The Economist, 200612 20, http://edwardlucas.blogspot.com/2006/12/ spy-stories.html . 


\section{Literatūros apžvalga}

Žvalgyba yra dažna politinių ir akademinių diskusijų tema, Lietuvos žvalgybos diskursas iki šiol išlieka gana skurdus. Iki šiol nèra išliesta nei viena rimta mokslinė publikacija šiuolaikinės žvalgybos tema. Dauguma paskelbtu publikacijų nagrinëja dabartines politines aktualijas arba žvelgia į žvalgybą iš istorinės perspektyvos. Lietuvos aukštosiose mokyklose beveik nẻra programų, kuriose būtų pristatomi žvalgybos pagrindai. Išimtimi galima būtų laikyti Antano Pranskevičiaus Vilniaus universitete Tarptautinių santykių ir politikos mokslų institute dėstomą kursą Sovietų Sajungos/Rusijos specialiosios tarnybos.

Vieninteliu šiuolaikiniu bandymu ,ivesti“ žvalgybos tarnybas į platesnị kontekstą yra Gintaro Bagdono „Karde“ išspausdintas straipsnis „Slaptuju žvalgybos tarnybu vaidmuo ir kontrolè demokratinëje valstybëje“, kuriame pristatomos žvalgybos tarnybų funkcijos ir jų santykiais su įstatymų leidžiamosios valdžios atstovais ${ }^{2}$. Bagdonas savo darbe bando pateikti teorinius žvalgybos tarnybų vietos demokratinejje visuomenëje modelius, tačiau labai nenoriai kalba apie Lietuvos patirtį šioje srityje. Žvalgybos tarnybos darbo metodai kovoje prieš terorizmą pristatomi Arūno Paukštės 2006 m. apgintoje

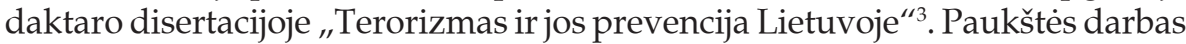
išsiskiria tuo, kad bando suderinti kovos su terorizmu praktiką su teorija, deja, žvalgybos funkcijos šioje kovoje minimos prabėgomis, o VSD veikla vertinama tik teigiamai. Bagdono ir Paukštès darbus vienija tai, kad abu dirba institucijose, susijusiose su žvalgyba (Bagdonas - karinės žvalgybos atstovas, Paukšte - VSD darbuotojas), ir bando apžvelgti i žvalgybos tarnybos veiklą iš teorinès perspektyvos. Tačiau, būdami valstybės pareigūnai, jie išlieka suvaržyti instituciniu gniaužtu ir negali pateikti kritinio požiūrio i̇ savo darbo pobūdị.

Atskirai galima būtų minèti keturių autorių - Egdūno Račiaus, Astos Maskaliūnaitės, Deivido Šlekio ir Vaidoto Urbelio - monografiją „Tarptautinès antiteroristinès kovos iššūkių Lietuvai analize் ${ }^{\prime \prime 4}$. Jos vienas skyrius yra skirtas Lietuvos instituciju pasirengimo teroristiniams aktams analizei, kuriame kalbame ir apie žvalgybos tarnybų indèli i i terorizmo prevenciją.

Labai svarbus šaltinis, analizuojant žvalgybos tarnybų veiklą Lietuvoje, yra Seimo nacionalinio saugumo ir gynybos komiteto (NSGK) atlikto parlamentinio VSD tyrimo dẻl saugumo karininko Pociūno žūties medžiaga. Internete paskelbtose stenogramose gana aiškiai matyti VSD darbo pobūdis ir netgi ju struktūriniu padalinių veiklos kryptys. Panašaus detalumo medžiagos apie AOTD darbą, deja, nėra. Geriausiu šaltiniu apie AOTD darbą kol kas išlieka

\footnotetext{
2 Bagdonas G., ,Slaptujų žvalgybos tarnybų vaidmuo ir kontrolè demokratinèje valstybėje“, Kardas, 2 (419), 2006, p. 10-16.

3 Paukšte A. „Terorizmas ir jo prevencija Lietuvoje“, daktaro disertacija, Mykolo Romerio universitetas, Vilnius, 2006, 196 lap.

${ }^{4}$ Račius E., Maskaliūnaite A., Šlekys E., Urbelis V. Tarptautinès antiteroristinès kovos iššūkiu Lietuvai analizé, Vilnius, Vilniaus universiteto leidykla, 2007.
} 
jos vadovu interviu spaudoje ir 2008 m. pabaigoje pasirodęs „Krašto apsauga“ numeris, skirtas žvalgybos tematikai ${ }^{5}$.

I žvalgybos ekspertų vaidmenị pretenduoja buvęs „Valstiečių laikraščio" priedo „Vardan Lietuvos" redaktorius Gintaras Visockas ir buvęs AOTD personalo skyriaus viršininkas Kęstutis Kaminskas. 2006 m. jie išleido publicistinio pobūdžio knygą "Žvalgybu intrigos Lietuvoje, 1994-2006“6, kurios antras leidimas pasirode $2007 \mathrm{~m}$. pabaigoje. Deja, ši knyga apsiriboja atskiru asmenų veiklos komentavimu, joje neaptiksime bandymu pateikti sistemišką Lietuvos žvalgybos tarnybų analizę. Knygoje pasitaiko nemažai faktų klaidų, o kai kurie jos skyriai primena sąskaitų su buvusiais kolegomis suvedinėjimą, o ne rimtą požiūrị i žvalgybos tarnybų veiklą. Todèl ši knyga, kaip ir šių asmenu redaguojamas „XXI amžiaus" priedas „Slaptieji takai“ ir Visocko internetinis puslapis Slaptai.lt šiame straipsnyje nėra pripažistami kaip patikimi šaltiniai, kurie pateikia objektyvu žvalgybos tarnybų veiklos vaizdą Lietuvoje, nors pripažịstama, kad juose galima aptikti ir tikrai įdomių ižzalgu. Panašiai galima vertinti ir buvusio Seimo Nacionalinio saugumo ir gynybos komiteto pirmininko Algimanto Matulevičiaus publicistinio pobūdžio knygą „Valstybės valdymo užkulisiai“, kur nemaža vietos skiriama VSD darbui aptarti .

Publikaciju parašytų iš istorinės perspektyvos yra kur kas daugiau. Arvydo Anušausko knyga „Lietuvos slaptosios tarnybos, 1918-1940“8 yra puiki tarpukario Lietuvos žvalgybos apžvalga, kurioje istoriko žvilgsniu pristatoma to laikotarpio Lietuvos žvalgybos tarnybų veikla, evoliucija ir likvidavimas. Knygoje gausu faktinės medžiagos ir tikrų istorijų iš tarpukario Lietuvos žvalgybos tarnybu gyvenimo. Deja, istorinè perspektyva neleido autoriui detaliau pažvelgti į žvalgybos tarnybos veiklos pobūdị, neaiškus terminu vartojimas (pavyzdžiui, terminas „kontržvalgyba“ vartojamas įvairiomis prasmèmis), o pagrindinè išvada, kad tarpukario laikotarpiu Lietuvos žvalgybos tarnybos pasivijo Vakarų Europos valstybių analogiškų tarnybų lygi, nėra grindžiama svariais argumentais. Su pačia Lietuvos žvalgybos tarnybų kūrimosi pradžia galima susipažinti ir 1921-1923 m. buvusio Lietuvos kariuomenės Generalinio štabo kontržvalgybos viršininko Jono Budrio knygoje „Atsiminimai. Kontržvalgyba Lietuvoje ${ }^{\text {«9 }}$. Joje detaliai aprašyti pirmieji Lietuvos žvalgybos kūrimosi metai, kova su lenkais, generolo K. Kleščinskio sulaikymo istorija.

Istorine perspektyva dvelkia ir žurnale „Kardas“ 2008 m. pradètas skelbti Alberto Daugirdo straipsnių ciklas „Ž̌valgybos evoliucija: istoriniai pavyzdžiai ${ }^{{ }^{\prime 10}}$. Savo straipsniuose Daugirdas bando pažvelgti, kaip žvalgybinè informacija paveikdavo karų ar mūšio baigtị. Deja, pateiktose istorijose beveik nerandame paties autoriaus įžvalgų ar analizès, o nemažai pavyzdžių perdètai sureikšmina žvalgybinès informacijos reikšmę. „,Kario“ žurnale Manvydas Vitkūnas straips-

\footnotetext{
5 Krašto apsauga, 18 (147).

6 Visockas G., Kaminskas K. Žvalgybu intrigos Lietuvoje, 1994-2006, Vilnius, Spauda, 2006.

Matulevičius A. Valstybès valdymo užkulisiai, Vilnius, Algarvė, 2008.

8 Anušauskas A. Lietuvos slaptosios tarnybos, 1918-1940, Vilnius, Mintis, 1993.

9 Budrys J. Atsiminimai. Kontržvalgyba Lietuvoje, Vilnius, Žaltvykstė, 1991.

${ }^{10}$ Daugirdas A., ,Žvalgybos evoliucija: istoriniai pavyzdžiai“, Kardas, 4 (6), 2008.
} 
nyje „Kryžiuočių ordino žvalgyba prieš Lietuvą“ apžvelgia kitos pusės pastangas žvalgyti Lietuvos teritoriją ${ }^{11}$. Trumpa Lietuvos Didžiosios Kunigaikštystès žvalgybos istorija pateikiama 2008 m. specialiame žvalgybai skirtame „Karšto apsaugos" numeryje ${ }^{12}$.

Pokario metams skirtos literatūros nèra gausu. Genocido ir rezistencijos centro publikacijose dažnai aptariami NKVD ir kitų sovietų represinių struktūru veiklos Lietuvoje metodai. Apie partizanų veiklą rašè Dalia Kuodytė, Kęstutis Girnius ir kiti autoriai, tačiau nei vienas iš ju specifiškai nesidomejjo partizanu žvalgybos pajègumais.

Svarbus istorinis informacijos šaltinis yra buvusių žvalgų prisiminimai arba pagal jas išleistos grožinès literatūros knygos. Ne visos iš ju yra patikimi informacijos šaltiniai, dažnai, vaikydamiesi populiarumo, autoriai iškreipia ar sufabrikuoja tam tikrą informaciją. Tačiau tokios knygos pateikia daugybę pavydžių iš praktinio gyvenimo, kaip buvo ar nebuvo panaudota žvalgybinė informacija. Be to, nemažai iš šių knygų autorių mini ir Lietuvą, ypatingai rašydami apie Sovietų Sajungos griūtį. Tokių knygų pavyzdžiai - buvusio KGB darbuotojo Sergejaus Tretyakovo atsiminimais paremta Petes Early knyga Comrade J. ${ }^{13}$, buvusio GRU darbuotojo, perbėgusio pas britus, Viktoro Suvorovo pagarsejjusi knyga Inside Soviet Military Intelligence ${ }^{14}$, buvusio CIA darbuotojo Milto Beardeno prisiminimais paremta knyga The Main Enemy. The Inside Story of the CIA's Final Showdown with the KGB ${ }^{15}$, pagal buvusio KGB archyvaro Vasilijaus Mitrochino pergabentų į Didžiąją Britaniją dokumentus kartu su Christopherio Andrew išleista knyga The Sword and the Shield ${ }^{16}$ ar net lietuvio KGB karininko Ričardo Vaigausko prisiminimai Slaptajame protu kare: tarybinio žvalgo prisiminimai ${ }^{17}$. Tokių knygu išleista daugybè, todèl labai svarbu atsirinkti tas, kurios nedaug nukrypsta nuo teisybės, ir nèra pagrįstos autoriaus išsigalvojimais (kaip, pavyzdžiui, Tomo Clancy romanai).

Lietuvos periodinejje spaudoje pasirodančios publikacijos dažniausiai nagrinëja Lietuvos žvalgybos tarnybų politines aktualijas, ir daugiausia dèmesio skiria jų vadovų asmeninių reikalų aptarimui (Mečio Laurinkaus, Arvydo Pociaus, Povilo Malakausko, Gintaro Bagdono ir kitų). Šiose publikacijose nèra bandoma plačiau apžvelgti žvalgybos tarnybų veiklą, jų funkcijas, besikeičiančią jų padètị visuomenèje. Radijo ir televizijos komentarai taip pat daugiausia pateikia kasdieninę informaciją. Viena iš nedaugelio išimčių galima laikyti 2007 m. spalio 9 d.

\footnotetext{
${ }^{11}$ Manvydas Vitkūnas, „Kryžiuočių ordino žvalgyba prieš Lietuvą“, Karys, Nr 4 (433), p. 45-51.

12 Žvalgyba Lietuvos didžiojoje kunigaikštystejje, Krašto apsauga, Nr. 18 (147) 20081022 - 200811 05, p. $17-18$.

${ }^{13}$ Early P. Comrade J, P. Putnam's Sons, New York, 2007.

${ }^{14}$ Suvorov V. Inside Soviet Military Intelligence, London: MacMillan Publishing Company, 1984, http:// militera.lib.ru/research/suvorov8/index.html.

${ }^{15}$ Bearden M., Risen J., The Main Enemy. The Inside Story of the CIA's Final Showdown with the KGB, New York, Ballantine Books, 2004.

${ }^{16}$ Andrew Ch., Mitrokhin V., The Sword and the Shield, Basic Books, New York, 2001.

${ }^{17}$ Vaigauskas R., Slaptajame protu kare: tarybinio žvalgo prisiminimai, Vilnius, Politika, 2005.
} 
per LTV transliuotą Donskio laidą „Be pykčio“"18, kurioje gana atvirai savo prioritetus išdèstè būsimas VSD vadovas.

Lietuvos politinès partijos aktyviai dalyvavo diskusijose dèl Pociūno žūties ar tam tikrų VSD pareigūnų neetiškos veiklos, tačiau nepateikẻ savarankiškos visuotinės vizijos, kaip turètų atrodyti Lietuvos žvalgybos tarnybu veikla ateityje. Vienintelè Tẻvynès Sajunga $2007 \mathrm{~m}$. gruodžio 7 d. paskelbė dokumentą „Problemos VSD ir galimi jų sprendimo būdai“"19, kuriame bandoma pateikti ribotą žvalgybos tarnybos veiklos analizę, pavyzdžiui, jame gana profesionaliai parašytas skyrius apie žvalgybos ir kontržvalgybos funkciju atskyrimą, nors kituose skyriuose galima rasti loginių ir turinio klaidų, sąvokų painiavos. Šiame dokumente didžiausias dėmesys skiriamas organizaciniams dalykams - siūloma keisti žvalgybos tarnybų organizacinę struktūrą ir keisti jų valdymą. Kitos partijos savo rinkimų programose ar kituose dokumentuose visiškai nemini Lietuvos žvalgybos tarnybų veiklos.

Apibendrintai galima teigti, kad Lietuvos žvalgybos istorija dar nèra parašyta. Nors tarpukario laikotarpis nusipelnè tam tikro dėmesio, tai padaryta tik asmeninių Anušausko pastangu dèka. Tuo tarpu Lietuvos Didžiosios Kunigaikštystės istorija ir modernios Lietuvos žvalgybos sistema dar nėra tapusi nuodugnių akademinių studijų objektu.

\section{Lietuvos žvalgybos institucinè sandara}

Atkurtos Lietuvos žvalgybos istorija prasideda 1990 metais. Būtent 1990 m. kovo 26 d. Lietuvos Respublikos Vyriausybė įsteigė Valstybés saugumo departamentą. Šis keletą kartų keitè pavaldumą ir pavadinimą, tačiau jo statusas buvo apibrèžtas 1994 m. sausio 20 d., Seimui priẻmus Lietuvos Respublikos valstybės saugumo departamento statutą. Jo pirmais straipsnis skelbè, kad VSD yra Lietuvos Respublikos Seimui ir Respublikos Prezidentui atskaitinga valstybės institucija, kurios paskirtis - saugoti Lietuvos Respublikos suverenitetą ir jos konstitucinę santvarką. Dvigubas pavaldumas ir santykių su vykdomaja valdžia neapibrèžtumas vėliau tapo daugelio VSD problemu priežastimi.

Atkūrus VSD, svarbiausiu uždaviniu tapo surinkti ir išmokyti personalą. VSD daugeliu atveju teko imti žmones „iš gatvès“ ir per trumpą laiką mokyti juos darbo žvalgybinëje institucijoje. Virginijus Česnuliavičius teigia, kad pirmosiomis dienomis besąlygiškai, net į aukštas pareigas, buvo priimami KGB karininkai ir VRM ekonominès policijos (milicijos) darbuotojai. Tuo metu i tarnybą buvo priimami net vidurini išsilavinimą turintys asmenys, o apie kokias specialias žinias net nekalbama. Nuolat šlubavo saugumo tarnybu darbuotoju

\footnotetext{
${ }^{18}$ LTV laida „Be pykčio“, 2007 m. spalio 9 d.

${ }^{19}$ Tẻvynès Sajunga „Problemos VSD ir galimi jų sprendimo būdai“, http://www.naujadarbotvarke. lt $/$ ?id=23\&pg=\&nid=40.
} 
mokymo procesas ${ }^{20}$. Kadangi nebuvo vidinės kontrolės mechanizmo, daugelio darbuotoju patikimumą nustatyti buvo ypatingai sunku.

Tuo metu buvo pradèta bendrauti su Vakaru šaliu specialiosiomis tarnybomis, kurių dėmesys Baltijos šalims ypatingai išaugo, pradedant byrèti Sovietų Sajungai. $1991 \mathrm{~m}$. jau buvo užmegzti oficialūs kontaktai, o rugpjūčio mèn. Lietuvoje apsilanke pirmas Centrinès žvalgybos tarnybos (CŽV) pareigūnas Michaelis Sulickas. Kaip jis prisimena, pirmieji VSD vadovai neturëjo beveik jokio supratimo apie žvalgybos tarnybų darbą:

Laurinkus [Lietuvos žvalgybos vadovas] ir Butkevičius [naujas gynybos ministras] prisipažino mažai beišmaną apie žvalgybą. Laurinkus, kuris truputi kalbëjo angliškai ir buvo keletą kartų aplankęs savo gimines Massachusettse, parodė man dvi knygas. „tai viskas, ką aš žinau apie žvalgybą. Tai yra mano gidai, bet aš manau, kad ju nepakanka" - jis nervingai nusijuokè. Nei viena iš jo turimu knygu nebuvo CŽV rekomenduotinų knygų sąraše. Pirmoji buvo „CŽV dienoraštis“ parašyta Philipo Agee, kuris būdamas CŽV darbuotojas perdavè kubiečiams CŽV agentų Kuboje pavardes. Antroji buvo "CŽV ir žvalgybos kultas", 1974 m. parašyta Johno Markso ir Victoro Marchetti, dvieju dideliu CZZV kritiku. Max ${ }^{21}$ abi šias knygas buvo nusipirkęs Bostono knygyne, kai sužinojo, kad bus skiriamas VSD direktoriumi ${ }^{22}$.

Neigiamą įtaką VSD kūrimosi metu darè ir nuolatinė lyderiu kaita. VSD struktūrose vadovybè keitėsi daugiau nei penkis kartus. Iš pradžių VSD vadovavo Mečys Laurinkus, paskui Danukas Arlauskas, Viktoras Zedelis, Balys Gajauskas, Petras Plumpa. Tik $1993 \mathrm{~m}$. nusistovëjo ilgesnè ramybė-Jurgis Jurgelis vadovavo VSD penkerius, Laurinkus -šešerius metus. Būtent 1993-1994 metus galima vadinti persilaužimo laikotarpiu, kai bent iš dalies buvo sutvarkyta teisinè bazè, paskirti nuolatiniai vadovai, nustatyti konkretūs VSD uždaviniai, nustatyti prioritetai.

Karinė žvalgyba buvo atkurta $1990 \mathrm{~m}$. birželio 1 d. Krašto apsaugos departamente įkūrus Antrajį skyrių. Jis turëjo išsiaiškinti SSRS ginkluotuju pajėgų karinių dalinių dislokacija, jų paskirti, aktyvumą ir planuojamų veiksmų spektrą. Vèliau karinè žvalgyba buvo atskirta - strateginè žvalgyba ir kontržvalgyba tapo AOTD kompetencija, o kariuomenès operacinėms poreikiams tenkinti karinėse struktūrose (Gynybos štabe, pajègų štabuose ir karinių daliniu štabuose) buvo sukurti ,,antrieji skyriai“. Karinè žvalgyba susidūrè su tokiomis pačiomis problemomis kaip VSD, kurių svarbiausia - rasti žmoniu, galinčiu dirbti žvalgybinį ir kontržvalgybinį darbą - nebuvo profesionalių darbuotoju, trūko patirties. Karinė žvalgyba mažiau nei VSD rẻmėsi buvusių sovietinių darbuotojų patirtimi ${ }^{23}$.

Atkūrus karines ir civilines žvalgybos institucijas per pirmuosius ke-

\footnotetext{
${ }^{20}$ Gintaro Visocko interviu su Virginijumi Česnuliavičiumi „Slaptieji takai“ „XXI amžiaus“ priedas, 2007-iujų lapkričio 21 d., Nr. 9.

${ }^{21}$ MAX - Mečio Laurinkaus ,slapyvardis“.

${ }^{22}$ Sulick M. J., „As the USSR Collapsed: A CIA Officer in Lithuania Remembering 15 Years Ago“, Studies in Intelligence, 50(2),

https://www.cia.gov/library/center-for-the-study-of-intelligence/csi-publications/csi-studies/studies/vol50no2/html_files/CIA_Lithuania_1.htm.

${ }^{23}$ Gintaro Visocko interviu su Virginijumi Česnuliavičiumi „Slaptieji takai“. Ten pat.
} 
letą metų jos keitė savo funkcijas ir statusa, nors dabartinè žvalgybos institucijų sąranga nuo 1994 m. beveik nepakito. Tiesa, tikri pokyčiai vyko ir vėliau. Po 2000 m. nusistovëjo AOTD funkcijos - atsisakoma žvalgybos tarnybai nebūdingos veiklos, t. y. tardymas, kvota ir kita (perduota Karo policijai), ar ypatingai svarbiu asmenų apsauga (perduota Specialiosioms pajėgoms). Kariuomenès žvalgyba buvo vèl transformuota 2008 m., kai Krašto apsaugos ministerijos Gynybos štabe buvo panaikinta „antroji valdyba“ (J2), kuri vèliau atsirado Jungtiniame štabe, atsakingame už operacijų ir pratybu planavimą. VSD taip pat pertvarkè savo struktūrą, o 2006 m. įkūrè visiškai naują Kovos prieš terorizmą valdybą.

İdomu pastebèti, kad atkurtuju žvalgybos tarnybų pavadinimai ir funkcijos supanašèjo su 1935-1940 m. funkcionavusia sistema, kai už karinę žvalgybą ir kontržvalgybą atsako Krašto apsaugos ministerija, o už (nekarinę) žvalgybą ir kontržvalgybą - Valstybės saugumo departamentas. Skiriasi tik institucijų tiesioginis pavaldumas - 1935-1940 m. Kariuomenès štabo II skyrius buvo pavaldus kariuomenès vadui, o dabartinis Antrasis operatyvinių tarnybu departamentas yra tiesiogiai pavaldus krašto apsaugos ministrui. 1933-1940 m. VSD, nors ir turèjo didelę autonomiją, tačiau buvo pavaldus vidaus reikalu ministrui, dabar - Seimui ir Prezidentui.

Jau vèliau 2000 m. priimtas Lietuvos žvalgybos įstatymo 4 straipsnis nustatė žvalgybos tikslus, kurie iš esmès atitinka demokratinių šalių analogiškų tarnybų tikslus:

- aprūpinti Lietuvos Respublikos nacionalinį saugumą užtikrinančias valstybės institucijas žvalgybos informacija, reikalinga jų funkcijoms atlikti;

- sudaryti palankias sąlygas Lietuvos Respublikos nacionalinio saugumo ir užsienio politikai igyvendinti;

- nustatyti, mažinti ar šalinti nacionaliniam saugumui iš užsienio kylančias grèsmes bei rizikos veiksnius.

Tiesa, šie iš pirmo žvilgsnio standartiniai žvalgybos tarnybų tikslai gali būti vertinami gana plačiai. Pirma, îstatymo autoriai antrame punkte kalba apie „palankių sąlygų" sudarymą, tai turètų reikšti aktyvią žvalgybos tarnybų veiklą užsienio valstybėse ir valstybëje, įtakojant politinius, ekonominius ir kitus procesus. Tai labai sudètinga užduotis, kuri apimtų ne tik žvalgybinę veiklą - pavyzdžiui, palankaus valstybès įvaizdžio kūrimas, taip pat sudaro sąlygas tinkamai igyvendinti saugumo ir užsienio politiką. Žvalgyba gali būti ju kūrimo dalimi, bet jokiu būdu ne pagrindinè institucija, o tokią veiklą įvardinti kaip pagrindinę žvalgybos tarnybų funkciją būtų ne visiškai teisinga.

Antra, įstatymas pabrèžia žvalgybinės informacijos ir užsienio politikos glaudų sąryšį. Iš tikro žvalgybinè informacija turi ypatingą svarbą, formuluojant užsienio politikos žingsnius, o užsienio politiką vykdančios institucijos turètu būti pagrindinis žvalgybinės informacijos vartotojos (karinės žvalgybos - ginkluotosios pajėgos ir gynybos planuotojai). Šis punktas yra teisingas, tačiau jo igyvendinimas Lietuvoje yra gana epizodinis.

Trečia, įstatymas trečiame punkte leidžia žvalgybos tarnyboms „,šalinti“ 
iš užsienio kylančias grèsmes. Šis punktas yra labai sudètingas, ir apima ne tik kontržvalgybą, bet ir kitas priemones, įskaitant ir priedangos operacijas užsienio valstybėse. Keista tik tai, kad "grèsmių šalinimas" neapima grėsmiu, kylančių „iš vidaus“, nors VSD ir turi plačius igaliojimus veikti valstybės viduje.

Visi šie funkciniai prieštaravimai ir neaiškumai nèra tokie dideli, kad sudarytų kliūtis žvalgybos tarnyboms vykdyti jų kasdieninius darbus. 1993-1994 m., nustačius pagrindinius žvalgybos tarnybų veiklos principus, pradejjo augti informacijos rinkimo, analizès pajègumai, o Lietuvos žvalgybos tarnybos èmè panašèti į žvalgybos tarnybas NATO ir ES šalyse.

\subsection{Institucinès sąrangos modeliai}

Visų šalių žvalgybos tarnybas teoriškai galima organizuoti, remiantis įvairiais pjūviais. Nèra vieno modelio, kaip turètų būti organizuotas jų darbas, todèl kiekviena valstybẻ skirtingai sprendžia funkcijų padalinimą tarp įvairių žvalgybos tarnybų. Galima būtų išskirti šiuos pagrindinius pjūvius:

- Pagal sritis: karinė žvalgyba ir nekarinè žvalgyba; kaip karinės žvalgybos elementas atskirai išskiriama kariuomenès žvalgyba, kuri atsakinga už paramą vykdomoms operacijoms;

- Pagal informacijos rinkimo metodus: visų rūšių žvalgyba ar žvalgyba, paremta vienu informacijos rinkimo metodu (pavyzdžiui, ryšių žvalgyba);

- Pagal tikslą: žvalgyba (siekiant gauti informaciją) ir kontržvalgyba (siekiant saugoti informaciją). Kai kuriuose šaltiniuose žvalgybinė funkcija sutapatinama su užsienio žvalgyba, o kontržvalgyba - su vidaus žvalgyba, tačiau dauguma ekspertų vengia vidaus ir užsienio žvalgybos terminų vartojimo.

Praktikoje žvalgybos tarnybų šalyse svyruoja nuo vienos Liuksemburge iki šešiolikos JAV. Bjorno Mullerio-Wille nuomone, beveik kiekviena šalis gali turèti vieną ar keletą agentūru, kurios teikia paramą sprendimų prièmėjams tam tikrose srityse ${ }^{24}$ :

- Karinės žvalgybos renka ir vertina informaciją apie užsienio kariuomeniu esamą ir numatomą pajègumą savo ir kitų valstybių teritorijose. Tokios tarnybos dažniausiai priklauso gynybos ministerijoms ${ }^{25}$;

- Saugumo žvalgybos domisi grèsmėmis šalies konstitucinei tvarkai. Joms

\footnotetext{
${ }^{24}$ Muller-Wille B. „For our Eyes Only? Shaping an intelligence community within the EU“, European Union Insitute for Security Studies, Occasional paper N. 50, January 2004, p. 8-9.

${ }^{25}$ Pavyzdžiai: JAV Gynybos žvalgybos agentūra (angl. Defense Intelligence Agency), Didžiosios Britanijos Gynybos žvalgybos štabas (angl. Defence Intelligence Staff), Rusijos Vyriausioji žvalgybos valdyba (rus. Glavnoye Razvedyvatelnoye Upravlenie), Vokietijos karinės apsaugos tarnyba (vok. Militärischer Abschirmdienst) ar ị kariuomenès poreikius orientuotos JAV armijos karinè žvalgyba (angl. Army Military Intelligence), Didžiosios Britanijos žvalgybos korpusas (angl. Intelligence Corps).
} 
dažniausiai pavedama kontržvalgybos funkcija, taip pat „,kairiojo“ ir "dešiniojo" ekstremizmo stebejjimas ir kova su terorizmu ${ }^{26}$. Neretai saugumo žvalgybos ir kontržvalgybos terminai naudojami kaip sinonimai.

- Kriminalinė žvalgyba kovoja su organizuotu nusikalstamumu. Šio pobūdžio tarnybų funkcijos skiriasi tuo, kad jos veda kriminalines bylas, todèl jos renka įrodymus taip, kad juos galima būtų panaudoti teisme ${ }^{27}$;

- Užsienio žvalgybos stebi įvykius užsienio šalyse. Jos teikia paramą šalies užsienio politikos formuotojams, taip pat rengia užsienio valstybiu saugumo, gynybos ar ekonominius vertinimus. Skirtingai negu kitos tarnybos, užsienio žvalgyba skirta valstybès politikai, o ne operacijoms paremti. Todèl jos darbo rezultatai ne tokie išsamūs, jais lengviau dalintis su kitomis tarnybomis ${ }^{28}$.

Nei viena valstybė neišgali turèti daugybės žvalgybos instituciju, kurios dirbtų viename atskirame segmente. Daugiausia valstybėse, pavyzdžiui, egzistuoja atskirtos karinės ir nekarinės žvalgybos, nors Norvegijoje, Suomijoje, Švedijoje ir Danijoje užsienio žvalgybos tarnybos yra karinės tarnybos, kurios priklauso gynybos ministerijai ${ }^{29}$. Kitos valstybės išlaiko žvalgybos tarnybas, kurios taiko tik tam tikrą informacijos rinkimo metodą (pavyzdžiui, signalu žvalgyba), tačiau dažniausiai mažos valstybès neturi pakankamai ištekliu tokiai veiklai.

Nagrinėjant daugumo valstybių institucinę sąrangą, galima daryti išvadą, kad daugelis valstybių išlaiko saugumo žvalgybą/kontržvalgybą (panašios funkcijos i VSD) ir karines žvalgybas (panašios i AOTD). Tiesa, nemažai valstybių žvalgybos bendruomenè yra daug platesnè - pavyzdžiui, beveik visų valstybių kariuomenès turi atskirtas žvalgybos tarnybas, skirtas jų poreikiams patenkinti - JAV sausumo pajėgų žvalgyba (angl. Army Intelligence), Jūru pajègu žvalgyba (angl. Navy Intelligence). Žvalgybos bendruomenė gali apimti ir kitas ekonominio ar kriminalinio pobūdžio agentūras (pavyzdžiui, JAV terorizmo ir finansinės žvalgybos tarnyba prie Finansų departamento (angl. Office of Terrorism and Financial Intelligence under the United States Department of the Treasury) arba Kovos su narkotikais administracija prie Teisingumo departamento (angl. Drug Enforcement Administration under the United States Department of Justice).

Lietuvoje pagal LR žvalgybos įstatymą veikia dvi nacionalinės žvalgy-

\footnotetext{
${ }^{26}$ Pavyzdžiai: JAV dalis Federalinio tyrimų biuro (angl. Federal Bureau of Investigation), Didžiosios Britanijos saugumo tarnyba, žinima kaip MI5 (angl. Security Service), Rusijos Federalinė saugumo tarnyba (rus. Federalnaya Sluzhba Bezopasnosti), Vokietijos Konstitucijos apsaugos tarnyba (vok. Verfassungsschutz).

${ }^{27}$ Pavyzdžiai: dalis JAV Federalinio tyrimų biuro (angl. Federal Bureau of Investigation), Didžiosios Britanijos policijos žvalgyba (angl. Police Intelligence).

${ }^{28}$ Pavyzdžiai: JAV centrinė žvalgybos tarnyba (angl. Central Intelligence Agency), Didžiosios Britanijos slaptoji žvalgybos tarnyba, žinoma kaip MI6 (angl. Secret Intelligence Service), Rusijos užsienio žvalgybos tarnyba (rus. Sluzhba Vneshney Razvedki), Vokietijos Federalinė žvalgybos tarnyba (vok. Bundesnachrichtendienst), Prancūzijos generalinis užsienio saugumo direktoratas (pranc. Direction Générale de la Sécurité Extérieure).

${ }^{29}$ Gintaras Bagdonas, Žvalgybinès ir teisèsauginès veiklos tarpusavio santykio nustatymo svarba: užsienio šaliu patirtis, Konferencija „Būti ar nebūti“, Operatyvinès veiklos įstatymo vieta Lietuvos teisinèje sistemoje, 2006 m. gegužès 26d., Vilnius.
} 
bos ir saugumo institucijos: Valstybès saugumo departamentas ir AOTD prie Krašto apsaugos ministerijos. Šios tarnybos darbo sferas pasidalinusios pagal funkcini pjūvi - AOTD užsiima tik karine žvalgyba, o VSD tenka visos kitos žvalgybos sritys (ekonominè, saugumo ir t. t.). Jei lygintume su VSD, AOTD vykdama veikla yra labiau specifiškai apibrėžta - pavyzdžiui, kovoje su terorizmu ji domisi tik tomis terorizmo apraiškomis, kurios gali kelti grèsmę Lietuvos karinėms misijoms užsienyje (Afganistane, Irake) ir krašto apsaugos sistemai Lietuvoje ${ }^{30}$. AOTD yra tik kariné žvalgyba, nors dẻl nauju grèsmiu transnacionalinio pobūdžio bei ryšių su tarptautiniu nusikalstamumu, jos veikla vis tampriau siejasi su VSD funkcijomis. Keista, kad LR žvalgybos įstatymas neįtraukè į žvalgybos bendruomenę kariuomenės žvalgybos, kriminalinio ar ekonominio pobūdžio žvalgybos tarnybų. Toks dirbtinis žvalgybos iૃrèminimas iš dalies stabdo žvalgybinès bendruomenès plètrą ir jos pajėgumų didèjimą už VSD ir AOTD ribų.

Pagal įstatymus VSD ir AOTD turi teisę rinkti informaciją visais įstatymų leidžiamais būdais, Lietuvoje priešingai nei didžiosiose valstybėse nẻra instituciju, kurios užsiimtų tik atskiros srities informacijos rinkimu (pavyzdžiui, žmoniškoji arba atvirų šaltinių žvalgyba). Abi žvalgybos tarnybos turi atskirus kontržvalgybos padalinius. Abi žvalgybos tarnybos renka informaciją tiek valstybès viduje, tiek už ribų.

Dabartinis funkcijų padalinimas turi nemažai privalumų. Jis gana aiškiai atskiria funkcijas ir kiekvienos institucijos teises, gana aiškiai reglamentuoja atsakomybę už savo veiklą ir neišskaido žvalgybinės veiklos po įvairias institucijas. Kita vertus, toks funkcijų rinkinys, kurį turi VSD, yra per platus, t. y. institucijos, kuri derintų ir užsienio žvalgybos, ir vidaus saugumo tarnybos, ir teisėsaugos funkcijas, demokratinėse šalyse aptikti nepavyko.

Lietuvoje galima išgirsti ịvairių siūlymu, kaip keisti dabartinį modelị. Pavyzdžiui, Laurinkus ragina atskirti vidinę ir užsienio žvalgybą - reikia „peržiūrèti VSD priskirtas funkcijas. VSD turètų užsiimti tik užsienio žvalgyba ir kontržvalgyba ${ }^{31 " . ~ T e ̀ v y n e ̀ s ~ s a ̨ j u n g o s ~ n a r e ̀ ~ R a s a ~ J u k n e v i c ̌ i e n e ̇ ~ s i u ̄ l o ~ a t s k i r t i ~}$ žvalgybą ir kontržvalgybą, ir VSD labiau koncentruotis į kontržvalgybos funkciją ${ }^{32}$.

Tiek dabartinis, tiek Laurinkaus ar Juknevičienės siūlomi variantai yra galimi Lietuvoje, nors žvalgybos tarnybų skaičius ir funkcijų pasidalinimas turètų atitikti tam tikrus principus. Visų pirma žvalgybos tarnybų neturètų būti per daug. Kiekvienos naujos tarnybos išlaikymas iš karto didina administracinị aparatą ir sunkina keitimosi informacija galimybes.

Antra, didelès vienos tarnybos sukūrimas, nors ir leistų sutaupyti, tačiau sukurtų keletą problemų - pirma, išnyktų sveika konkurencija tam tikrose

\footnotetext{
${ }^{30}$ Krašto apsaugos ministerija, Ministerija, Karinė žvalgyba ir kontržvalgyba, Istorija, veikla, http://www. kam.lt/index.php/lt/34341/.

${ }^{31}$ Slaptieji agentai neišsivaduoja iš ịtakų verpeto, Kauno diena, 200609 16, 212 (17976).

${ }^{32}$ Rasa Juknevičienè, Rimtu problemu sprendimas tik imituojamas, 200805 15, http://www.bernardinai.lt/ index.php?url=articles/78819.
} 
srityse (pavyzdžiui, saugumo situacija Rusijoje yra svarbus tiek AOTD, tiek VSD analizės objektas). Dauguma valstybių i žvalgybos procesą įveda tam tikrus konkurencijos elementus, o tai leidžia skirtingoms žvalgybos tarnyboms savarankiškai pateikti tam tikrų reiškinių analizę arba atskirą poziciją. Marko Lowenthalio nuomone „dauguma žvalgybos agentūru tiki, kad konkurencinė analizė leis išvengti grupinio mąstymo ir prievarta brukamo susitarimo" ${ }^{\prime 33}$. Dirbtinis bandymas suderinti skirtingas žvalgybos tarnybų pozicijas gali padèti visiems rasti visiems priimtiną, bet ne provokacinį ar aštrų analizès pateikimą.

Trečia, tarnybos neturètų dominuoti viena kitos atžvilgiu. Kitaip dominuojanti tarnyba valdytų didžiulę informaciją ir, susiklosčius tam tikroms aplinkybėms, galètų tapti svarbiu politiniu veikejju Lietuvoje. Pavyzdžiui, Malakauskas LTV laidoje „Be pykčio“34 gynė savotišką Lietuvos žvalgybos tarnybų konkurenciją. Jo nuomone, yra logiška, kad operatyvinès tarnybos priklauso skirtingoms tarnyboms - dalis Seimui, dalis - Vyriausybei. Tai jis aiškina rizikinga šalies geopolitine situacija, o hierarchinė tokių tarnybų struktūra, jo nuomone, gali turèti neigiamu pasekmių - jeigu viena tarnyba turès problemu, tai jos persikels į kitas.

Lietuvos žvalgybos bendruomenè turès plèstis, o jos struktūra bus peržiūrèta. Tačiau jos plètra gali vykti tik ten, kur jaučiamas žvalgybinès informacijos poreikis ir kur jau egzistuoja žvalgybinės informacijos rinkimo pradmenys. Dabartinės žvalgybos tarnybų funkcijos turètų būti peržiūrètos, tačiau ši peržiūra neturètų keisti svarbiausių dabartinės sandaros pamatų.

\subsection{Pavaldumas}

Dèl žvalgybinès informacijos ir veiklos specifikos, žvalgybos tarnybos beveik visose valstybėse tiesiogiai pavaldžios aukščiausiems šalies pareigūnams - šalių prezidentams ar ministrams pirmininkams, o karinès žvalgybos - gynybos ministrams. Toks pavaldumas pagrįstas paprasta logika - pirma, žvalgybos tarnybų teikiama informacija yra skirta paremti, priimant svarbius užsienio ir vidaus politikos sprendimus. Šie sprendimai dažniausiai yra Vyriausybès arba tam tikro ministro kompetencija. Antra, kai kurie žvalgybos tarnybų veiksmai reikalauja politikų pritarimo (ypač priedangos operacijos), tokių sprendimų politikai negali deleguoti valstybès tarnautojams ar leisti žvalgybos tarnyboms veikti savarankiškai.

Dabar AOTD tiesiogiai pavaldi krašto apsaugos ministrui. Tai atitinka demokratinių šalių praktiką. Krašto apsaugos ministras turi teisę formuluoti jai užduotis, vykdyti jos vertinimą, skirti ir atleisti vadovus. Tiesioginis pavaldumas nereiškia, kad ministras yra pagrindinis AOTD rengiamos informacijos vartotojas, tačiau jis privalo išlaikyti politinę AOTD kontrolę.

\footnotetext{
${ }^{33}$ Lowenthal M. Intelligence: From Secrets to Policy, (3rd Edition), Washington DC: CQ Press, 2005, p. 8.

${ }^{34}$ LTV laida „Be pykčio“, 20071009.
} 
Dvigubas VSD pavaldumas sukelia daugiau klausimų. Pavyzdžiui, nelabai aišku, kas atsakingas už VSD užduočių formulavimą, jų vykdymo kontrolę ir priežiūrą. Klausimas, kurị 1940 m. uždavė Didžiosios Britanijos ministrui pirmininkui Winstonas Churchillis „,kas čia atsakingas?“"35 arba perfrazuojant, „kuris pareigūnas kalba žvalgybos tarnybų vardu?", yra ypatingai taiklus, svarstant žvalgybos tarnybu pavaldumą Lietuvoje.

VSD dvigubas pavaldumas Seimui ir Prezidentui kelia ne tik ekspertu, bet ir politiku susierzinimą. Seimo narẻ Juknevičienė problemą suformulavo taip: , pirmas dalykas - būtina kelti klausimą dèl VSD pavaldumo. Ar jis ir toliau lieka pakabintas beorèj erdvëj tarp Prezidentūros ir Seimo, kur iš esmès niekas neformuluoja užduočiu ir negali prisiimti atsakomybės“36? Tẻvynės Sajunga taip pat gana pagrịstai teigia, kad „Prezidentas su VSD dirba per vieninteli savo patarëją, kuri, beje, deleguoja pats VSD. Seimas negali ir niekada negalès dẻl savo prigimties užsiimti kasdienine kontrole ar tuo labiau valdymu. VSD iškrenta iš valstybės nacionalinį saugumą užtikrinančios sistemos. Ji yra atskira, nepriklausoma organizacija“37.

Tėvynès Sajungos keliamai problemai pritaria ir buvęs VSD vadovas Laurinkus. Jo nuomone, ,,dabar informaciją VSD teikia visiems trims aukščiausiems šalies vadovams, tada ir kyla nesusipratimas, kodèl vienas gavo anksčiau, kitas -vèliau. Turi būti aiškiai nustatyta institucija, kuriai pavaldi VSD”338.

Ypač aktualus VSD santykis su Vyriausybe. Žiūrint iš teorinès perspektyvos, žvalgybos tarnybos turètų būti vyriausybių rankose, nes žvalgybos tarnybos turi užtikrinti nuolatinị jų aprūpinimą informacija bei padèti iggyvendinti kitus vyriausybės planus ${ }^{39}$. Juknevičienè pabrèžè, kad „,nors Konstitucijoje nurodyta, kad nacionalinis saugumas yra Vyriausybės reikalas, tačiau kasmetineje Vyriausybės ataskaitoje nieko apie tai neužsimenama. Paklaustas Vyriausybės vadovas atsako, kad esą VSD jam nepavaldus, ir šios srities jis negali komentuoti“" ${ }^{\prime 4}$.

Egzistuoja nemažai būdu, kaip sutvarkyti VSD pavaldumą. Tẻvynės Sajunga siūlo keletą problemos sprendimo modelių - pavyzdžiui, VSD tampa Vyriausybei pavaldžia institucija. Kitas būdas - nustatyti Vyriausybės didesni vaidmeni, išlaikant dabartinę VSD vietą ${ }^{41}$. Galimi ir kiti variantai - pavyzdžiui, Didžiojoje Britanijoje jungtinei žvalgybos tarybai (angl. Joint Intelligence Council - JIC) vadovauja Užsienio reikalų ministerijos atstovas, nors žvalgybos tarnybos gali savarankiškai bendrauti su Vyriausybės nariais.

Tiesa, Lietuvoje tokiu koordinatoriumi galètų būti ir šalies Prezidentas -

\footnotetext{
${ }^{35}$ Herman M., Intelligence Services in the Information Age, London, Frank Cass, 2005. p. 132.

${ }^{36}$ Rasa Juknevičienè, ,Rimtų problemų sprendimas tik imituojamas“, ten pat.

${ }^{37}$ Tèvynès sajunga, Problemos VSD ir galimi jų sprendimo būdai, Projektas, www.naujadarbotvarke. $1 \mathrm{t} / \mathrm{id}=24 \& \mathrm{did}=26$.

${ }^{38}$ Slaptieji agentai neišsivaduoja iš ittakų verpeto. Ten pat.

${ }^{39}$ Bagdonas, „Žvalgybinès ir teisèsauginès veiklos tarpusavio santykio nustatymo svarba“, ten pat.

${ }^{40}$ Rasa Juknevičienè, ,Rimtų problemų sprendimas tik imituojamas“, ten pat.

${ }^{41}$ R. Juknevičienè, ,Atsipalaidavimo būsena patogi šešèlinei valdžiai“, 200801 15, http://www.naujadarbotvarke. $1 \mathrm{t} /$ ?id=23\&nid=51.
} 
juk jis formuoja užsienio politiką. Jo komanda teoriškai galètų būti pagrindine užsienio žvalgybos gavëja, todèl užsienio žvalgyba galètų būti pavaldi ir jam. Ypač toks pavaldumas turètų prasmę, jei žvalgybos ir kontržvalgybos tarnybos būtų atskirtos. Tačiau, jei VSD išlaikytų teisèsaugos funkcijas, kur Prezidento igaliojimai yra labai riboti, tiesioginis dabartinio ar reformuoto VSD pavaldumas Vyriausybei būtų daug logiškesnis.

\section{3. Žvalgybos tarnybụ veiklos koordinavimas}

Žvalgybos tarnybų koordinacija vykdoma dviem būdais: hierarchiniu ir konsensualiniu. Pastaruoju atveju Didžiosios Britanijos jungtinėžvalgybos taryba yra bendra visų žvalgybos tarnybų institucija, o JAV prezidentinejje sistemoje nacionalinis žvalgybos direktorius (angl. Director National Intelligence - DNI) atstovauja visą žvalgybinę bendruomenę ${ }^{42}$.

- Konsensualinis modelis. Didžiojoje Britanijoje jungtinè žvalgybos taryba koordinuoja pagrindinių žvalgybos tarnybu (MI5, MI6, Vyriausybės ryšiu štabo (angl. Government Communications Headquarters), Gynybos žvalgybos štabo) darbą. Didžiojoje Britanijoje nèra centrinès analitinès tarnybos. Britanija pasikliauja departamentine, o ne centralizuoja sistema, kai konsensuso siekiama Jungtinëje žvalgybos taryboje ${ }^{43}$.

- Hierarchinis modelis. JAV sistemoje aiškiai apibrezžta, kad aukščiausias žvalgybos pareigūnas yra nacionalinis žvalgybos direktorius. Jis yra aukščiausias JAV žvalgybos pareigūnas, atsakingas prezidentui ir prižiūrintis Nacionalinės žvalgybos programos vykdymą ${ }^{44}$. Kiti du svarbūs veikëjai yra valstybės ir gynybos sekretoriai, jiems pavaldžioms žvalgybos tarnyboms nacionalinio žvalgybos direktoriaus įtaka kol kas nèra didelè.

Lietuvos fragmentuota sistema neatitinka nei vieno iš šių modelių. Lietuvoje nėra JAV pavyzdžiu „vyriausiojo žvalgo“ ar britišku pavyzdžiu koordinacinės struktūros, kuri užtikrintų žvalgybos tarnybų veiklos vieningumą. Ir nors teisiškai Lietuvoje egzistuoja tik dvi žvalgybą vykdančios institucijos, o tai turètų labai lengvinti jų bendradarbiavimą ir leistų nedubliuoti viena kitos funkciju, tačiau pats bendradarbiavimo mechanizmas nėra iki galo sugalvotas ir prastai veikia.

Pagal LR žvalgybos įstatymą Valstybės gynimo tarnyba (VGT) yra atsakinga už žvalgybos tarnybų veiklos koordinavimą, įskaitant užduočiu formulavimą. VGT sudaro Prezidentas, Ministras Pirmininkas, Seimo pirmininkas, krašto apsaugos ministras ir kariuomenès vadas. Tačiau Valstybės

\footnotetext{
${ }^{42}$ Herman, ten pat, p. 133

${ }^{43}$ Herman, ten pat, p. 132

${ }^{44}$ Stratfor US: Strenghtening the Power of ODNI, 200807 31, http://www.stratfor.biz/analysis/u_s strenghtening_power_odni.htm.
} 
gynimo tarybos įstatymo 7 straipsnis aiškiai sako, kad VGT nutarimai yra rekomendaciniai, i juos būtina atsižvelgti, tačiau sprendžiamosios galios VGT neturi. VGT sudètis taip pat nekoordinuoja ir nesudaro sąlygų efektyviam žvalgybos darbui. Pavyzdžiui, VGT nariais nėra užsienio reikalų ir vidaus reikalų ministrai, todèl šioje srityje jie turi mažesnę reikšmę, negu, tarkime, kariuomenès vadas ${ }^{45}$.

Tokia žvalgybos koordinavimo sistema yra ypatingai keista ir tuo, kad užsienio reikalų ministerija (URM) negali teisiškai formuoti užsienio žvalgybos poreikių ir prioritetų. URM pagal žvalgybos apibrėžimą yra bene pagrindinė užsienio žvalgybos (išskyrus karinès) informacijos vartotoja, o tiksli žvalgybinè informacija gali lemti geresnę poziciją tarptautinèse derybose. URM turi platų ambasadų tinkla, kurios taip pat užsiima informacijos apie užsienio šalis rinkimu. Tačiau LR žvalgybos įstatyme URM nèra net minima kaip dalyvaujanti institucija. URM taip pat neturi padalinio, kuris užsiimtų žvalgybinès informacijos dorojimu ar jo užsakymu. URM užsienio politikos analizès ir planavimo departamentas, kuriame tèra tik aštuoni žmonès, neturi jokių galimybių atlikti užsienio žvalgybos analizès funkcijų. URM analitinių padalinių trūkumą bandè spręsti pirkdama šią paslaugą iš Strateginių studijų centro ${ }^{46}$. Toks žingsnis padejo bent iš dalies spręsti problemą, nors viešoji įstaiga jokiu būdu negali būti pripažinta žvalgybos tarnybų pakaitalu.

Kiti žvalgybos produkcijos vartotojai - Prezidentas ir Ministras pirmininkas yra dar labiau atitolinti nuo žvalgybos proceso nei URM. Ju personalas beveik niekaip neįtakoja žvalgybos poreikių formavimo. Ministro Pirmininko ir Vyriausybès kanceliarijoje nèra nei vieno pareigūno, atsakingo už darbą su žvalgybos tarnybomis. Prezidentūroje dirba vienas VSD atstovas, tačiau, mažai tikètina, kad jis, kaip statutinis savo organizacijos atstovas, galètų Valstybès vadovui pateikti kritišką ir nešališką požiūrį apie savo atstovaujamos institucijos veiklą ${ }^{47}$. Todèl Valstybès gynimo tarybos kiekvienais metais tvirtinamas Žvalgybos planas yra daugiau formalus veiksmas nei realus užduočių žvalgybos tarnyboms formulavimo mechanizmas. Taigi pagal dabartinę sudètį ir turimus igaliojimus, VGT negali užtikrinti žvalgybinės veiklos koordinavimo.

Kitas, ne mažiau svarbus žvalgybos tarnybų veiklos aspektas, yra horizontalus bendradarbiavimas. Didžiujų valstybių patirtis (ypač JAV) rodo, kad būtent horizontalaus bendradarbiavimo trūkumas ir viena didžiausių žvalgybos tarnybu neefektyvumo priežasčių. Šis bendravimas turi apimti visus lygmenis - nuo vadovų iki specialistų.

Lietuvos žvalgybos tarnybų bendradarbiavimo sistema kol kas išlieka fragmentiška - tiesa, oficialiai deklaruojama, kad santykiai tarp kolegu yra puikūs, tačiau neoficialiai dauguma abiejų tarnybų darbuotoju pripažįsta,

\footnotetext{
${ }^{45}$ Jeigu Lietuvoje atsirastų atskira kariuomenès žvalgyba, kariuomenės vado dalyvavimas tvirtinat metini Žvalgybos planą igautų daug didesnę prasmę.

${ }^{46}$ Kai kuri centro produkcija, pavyzdžiui, informacinio pobūdžio „Rytų šalių i̇vykių ir procesų apžvalgos“ yra talpinamos ir internete http://www.ssc-lietuva.lt/index.php?id=35,0,0,1,0,0.

${ }^{47}$ Žr. Lietuvos Respublikos žvalgybos įstatymas, 2000 m. liepos 17 d. Nr. VIII-1861, http://www3.lrs.lt/pls/ inter3/dokpaieska.showdoc_1?p_id=171400
} 
kad bendradarbiavimas vyksta sunkiai, o kartais virsta atvira konkurencija. Tam tikri nesusipratimai iškyla net į žiniasklaidos paviršių, Vienas žinomiausių pavyzdžiu - VSD suėmimo operacija dẻl sprogstamų medžiagų laikymo Kaune, kurios metu buvo sulaikytas ne tik Vytauto Didžiojo jëgerių bataliono seržantas, bet ir AOTD pareigūnas Jonas Zajančkauskas ${ }^{48}$. Iš vieno incidento negalima daryti jokių išvadų apie bendradarbiavimą tarp VSD ir AOTD, ypač, jei viešai deklaruojama, kad santykiai tarp VSD ir AOTD bendradarbiavimas yra kaip niekad puikus ${ }^{49}$.

Reikètų prisiminti, kad ir tarpukariu Lietuvos karinės žvalgybos ir VSD santykiai nebuvo idealūs. Kariškiams nepatiko, kad VSD vykdo kontržvalgybos operacijas kariuomeneje, kurioje yra infiltravusi savo agentu. Nepasitenkinimas ryškiausiai prasiveržè nepasisekusio karinio pučo meto, kai „1934 m. birželio 7 d. kariuomene apsupo VSD pastatą, [...] o iš VSD valdininko Jasinsko išreikalavo departamento darbuotojų sąraš $0^{50 “} .1935 \mathrm{~m}$. krašto apsaugos ir vidaus reikalu ministrai bei VSD direktorius pasiraše ",bendradarbiavimo pagrindus“, kurie numate pasikeitimą informacija apie šnipinejjimą, sekimo išvadomis, schemomis ir panašia medžiaga. Susitarime nustatyta, kad karių sekimas iggulų teritorijoje priklauso kariškių, o už jų ribų - VSD kompetencijai ${ }^{51}$.

Viena iš svarbių horizontalaus bendradarbiavimo formų - apsikeitimas pareigūnais tarp instituciju. Nors Lietuvoje jis vyksta ganètinai vangiai, tačiau tai - teisinga kryptis. Pavyzdžiui, gerai yra išplètotas VSD ir URM bendradarbiavimas - VSD generalinio direktoriaus pavaduotojas yra diplomatas, ambasadose dirba VSD deleguoti saugumo pareigūnai. Lietuvos gynybos atašė akredituoti užsienio valstybėse taip pat padeda rinkti informaciją, nors jų funkcijos šiuolaikiniame pasaulyje vis labiau tolsta nuo "oficialaus žvalgo" statuso. VSD pareigūnas dirba prezidentūroje, kur kuruoja (?!) savo institucijos veiklą. KAM taip pat turi delegavusi savo atstovą į Prezidentūra, bet pagal

\footnotetext{
${ }^{48} \mathrm{BNS}$, A. Petrusevičiaus prekyba ginklais buvo vieša paslaptis, 200602 06, http://www.delfi.lt/news/daily/lithuania/article.php?id=8706665. Idomu tai, kad AOTD generalinis direktorius pulkininkas Gintaras Bagdonas tikino, kad jo nenustebino nei A.Petrusevičiaus, nei jo pavaldinio J. Zajančkausko suėmimas: „Reikètų atskirti patriotizmą, savanorius ir kriminalinius nusikaltimus. Aš tikrai ịsitikinęs, kad krašto apsaugos sistema nèra nusikalstama ir iš pavieniu atvejų negalima daryt išvados ir îvardint kaip masinio reiškinio. Tie pavieniai žmonès, nesveikas susidomejjimas ginklu, bet tai ne masinis reiškinys“", - sakẻ G. Bagdonas. AOTD vadovas tikino, kad iš neteisètu ginklų laikymu įtarto jo pavaldinio seniai atimtas leidimas dirbti su slapta informacija, tačiau nepaaiškino, kodẻl jis tiek metų toleruojamas karinės žvalgybos organizacijoje.

${ }^{49}$ BNS, Lietuvos karine žvalgyba: nuo agenčiu tarnaičiu iki NATO paslapčiu skydo, 200410 28, http:// www.bernardinai.lt/index.php?url=articles/26640.

Interviu su Gintaru Bagdonu: „Mes analizuojame galimus variantus, stebime i̇vykius, situaciją, tiek pradedant nuo Vidurio Azijos šalių, tiek Europoje, be abejo, čia keičiamės informacija su kitu šaliu karinėmis žvalgybomis. Keičiamės informacija su Valstybės saugumo departamentu. Bendradarbiavimas su juo, norečiau pabrèžti, yra vienas iš kertinių akmenų. Drįstu teigti, kad bendradarbiavimas tarp abieju šalies žvalgybinių institucijų - VSD ir AOTD - dabar kaip niekad gerai išplètotas. Bendradarbiaujama visomis kryptimis. Didžiausias dèmesys skiriamas informacijos apsaugai. Rengiantis stoti i NATO, informacijos apsauga buvo vienas iš svarbiausių punktų. Ir čia, naudodamasis proga, galiu pasididžiuoti - tikrai buvome įvertinti aukštu lygiu“.

${ }^{50}$ Anušauskas, ten pat, 1993, p. 206.

${ }^{51}$ Anušauskas, ten pat, 1993, p. 231.
} 
funkcijas jis nėra aktyvus žvalgybos proceso dalyvis. Šiame bendradarbiavime tarp instituciju trūksta tik vieno, bet svarbaus elemento - VSD ir AOTD glaudesnio bendradarbiavimo.

\subsection{Vidinè sandara}

Žvalgybos tarnybos niekada neatskleidžia savo vidinės struktūros ar darbo metodikos. Tačiau egzistuoja tam tikri principai, pagal kurios yra kuriama jų vidinè struktūra ir mažai tikètina, kad Lietuva sudaro išimtį iš bendro modelio. Dèl panašaus veiklos pobūdžio, tikètina, kad VSD ir AOTD struktūra ir darbo metodai turètų būtų labai panašūs. Abi tarnybos privalo turèti:

- informaciją apie užsienio valstybes apdorojantic padalinį (padalinius), kuris išnaudotų Lietuvos turimus informacijos diplomatinius šaltinius, užsienio valstybėse reziduojančius pareigūnus, kitų valstybių tarnybų pateiktą informaciją, laisvai pasiekiamą informaciją. VSD tuo užsiima Užsienio informacijos valdyba ${ }^{52}$;

- kontržvalgybos padalinius. VSD kontržvalgybos valdymą vykdo visos valstybès, AOTD - tik krašto apsaugos sistema. Dėl kontržvalgybos svarbos ir jos išskirtinumo, abiejų tarnybų vadovai turi pavaduotojus, kurie kuruoja kontržvalgybos sritį;

- funkcinius padalinius, skirtus vykdyti žvalgybą specifinėse srityse. VSD tokių padaliniu pavyzdžiai yra Kovos su terorizmu valdyba arba Ekonominio saugumo valdyba. Malakauskas netgi yra žadëjęs, kad energetinis valstybės saugumas bus jo vadovaujamos tarnybos prioritetas ${ }^{53}$;

- valstybės vidaus saugumu besirūpinanti padalinį, kuris seka visuomeninius ir politinius procesus. Ši funkcija - daugiausia VSD kompetencija, mažai tikètina, kad AOTD turètų panašią struktūrą (karinė žvalgyba greičiausiai apsiriboja informacijos krašto apsaugos sistemoje rinkimu pavyzdžiui, karių nuotaikų stebejjimas);

- tarptautinį bendradarbiavimą kuruojančius padalinius. Lietuvai tapus ES ir NATO nare, žvalgybinès informacijos srautai su sajungininkiu žvalgybos tarnybomis smarkiai išaugo. Nors dažnai bendradarbiaujama (pavyzdžiui, terorizmo specialistai kalbasi tiesiogiai su kitų šalių kolegomis), bet tam tikras veiklos koordinavimas yra būtinas;

- informacijos rinkimo technines priemones kuruojantys padaliniai. Nors kai kurių techninių priemonių Lietuva neturi (pavyzdžiui, žvalgybos palydovų), bet daugelyje sričių net ir mažos valstybės gali rinkti informaciją (pavyzdžiui, radijo ryšio, mobilaus ryšio pasiklausymas, elektroninė žvalgyba, šifrų ir kodų specialistai ir pan.). Šioje srityje veikia dvi

\footnotetext{
${ }^{52}$ Pateikiant VSD valdymu pavadinimus remtasi LRS NSGK VSD parlamentinio tyrimo stenograma

${ }^{53}$ Danulytė J. P., Malakauskas: energetinis saugumas - VSD prioritetas, 200805 27, DELFI, http://www. delfi.lt/news/daily/lithuania/article.php?id=17184635.
} 
žvalgybinei veiklai svarbios institucijos: Ryšių ir informacinių tarnybų sistema prie Krašto apsaugos ministerijos yra valstybëje atsakinga už kodavimą ir šifravimą, Vyriausybinių ryšių centras prie VSD - už valstybinio saugaus ryšio užtikrinimą;

- administracinius padalinius, kurie užtikrina kasdieninį tarnybų finansavimą (personalo, finansų ir kiti padaliniai, viešujų ryšių specialistai).

Kariuomenių žvalgybų struktūra truputi skiriasi - jos turi mažą centrinį aparatą ir karinių vienetų štabų antruosiuose skyriuose tarnaujančius žvalgus. Pastarieji yra pavaldūs savo dalinio vadui, tačiau kariuomenės žvalgybos vadovybė yra atsakinga už jų mokymą ir parengimą darbui. Taigi, nors kariuomenės vyriausiasis žvalgas beveik neturi sau pavaldžių daliniu, tačiau jo žmonès yra pasklidę po visą kariuomenę ir yra pasirengę suteikti paramą jos veiksmams. Lietuvoje, kaip ir visose šalyse, dalinių štabuose egzistuoja antrieji skyriai, tačiau nèra vyriausiojo žvalgo, kuris būtų atsakingas už jų darbo koordinavimą. Jungtinis štabas turi antrajji skyrių, tačiau jo kompetencija apsiriboja operaciju ir pratybų organizavimu.

\subsection{Resursai}

Žvalgyba, kaip ir kitos valstybės gyvenimo sferos, priklauso nuo joms skiriamų finansiniu, žmogiškujų ir kitų resursų kiekio. Modernios žvalgybos technologijos yra brangios, todèl daugelio šaliu žvalgybos tarnybos skiria pakankamą dẻmesį investicijoms ir nuolat atnaujina turimą techniką. Tačiau svarbiausias dėmesys skiriamas žmonių paruošimui, jų mokymui dirbti analitinį ar operatyvinį darbą. Žvalgybos tarnybos konkuruoja darbo rinkoje su komercinèmis firmomis, o buvę žvalgai yra laukiami privačiame sektoriuje. Ryšių žvalgybos specialistai lengvai randa darbą telekomunikacijų bendrovėse, operatyvininkai - saugos firmose, analitikai - mokslo institucijose. Dèl kylančiu atlyginimo privačiame sektoriuje žvalgybos tarnybos turi nuolat didinti išlaidas personalui, o tai trukdo investuoti į techninius pajègumus.

Lietuvos žvalgybos tarnybų biudžetas nuolat auga. VSD išlaidos yra laisvai nagrinejamos, tačiau AOTD biudžetas yra įslaptintas.

1 lentelè. VSD biužetas (mln.It)

\begin{tabular}{|c|c|c|c|c|c|c|c|c|c|}
\hline & 2001 & 2002 & 2003 & 2004 & 2005 & 2006 & 2007 & 2008 & 2009 \\
\hline $\begin{array}{c}\text { Valstybės } \\
\text { saugumo } \\
\text { departamentas }\end{array}$ & 33 & 45 & 47 & 35 & 55 & 65 & 68 & 76 & 63 \\
\hline $\begin{array}{c}\text { Vyriausybiniu } \\
\text { ryšiu centras } \\
\text { prie VSD }\end{array}$ & 3,7 & 4,4 & 4,4 & 6,1 & 6,2 & 6,9 & 7,7 & 11,4 & 8 \\
\hline
\end{tabular}


Jei lygintume su kitų šalių biudžetais ir žmogiškaisiais pajègumais, Lietuvos žvalgybos sistema yra ganėtinai maža ir neturtinga. Ypač skurdus investicinis VSD biudžetas - tik $20 \mathrm{mln}$. lt per metus (i juos nepatenka pinigai, skiriami naujojo pastato statybai). Mažai tikètina, kad už tokią sumą VSD galètų įsigyti modernių stebéjimo ir informacijos rinkimo priemonių ar pirkti informaciją iš privataus sektoriaus.

Biudžeto skaičiai leidžia apytiksliai nustatyti ir Lietuvos žvalgybos tarnybose dirbančiu žmonių skaičių. Pagal Seimo patvirtintą valstybės biudžetą, VSD personalui išleidžia 33 mln.lt. Darant prielaidą, kad viena darbo vieta kainuoja apie 60-80 tūkst. lt per metus, galima numanyti, kad VSD dirba apie 600 žmonių. Kadangi AOTD funkcijos yra mažesnès, galima spèti, kad jos personalo skaičius gali būti kelis mažesnis. Pridejjus visose kitose ịstaigose dirbančius pareigūnus, Lietuvos žvalgybos sistemoje tarnaujančiujų skaičius neturètu viršyti 1000 žmonių.

Šie žmonès - įvairių profesijų atstovai. Pirmieji žvalgybinès informacijos rinkimu ir analize Lietuvoje užsièmė ịvairių specialybių žmonès - buvę jègos struktūros atstovai („ekonomine policija“, kariškiai, policininkai, etc.), istorikai ir fizikai - būtent iš jų buvo suformuoti pirmieji VSD ir AOTD padaliniai. 1997 m., ịkūrus Specialiuju tyrimu tarnybą, dauguma personalo, tiriančio ekonominius nusikaltimus, perëjo į šią naujai sukurtą tarnybą. Vèliau analizès padaliniuose įsitvirtino socialinių mokslų atstovai, daugiausia - Vilniaus universiteto Tarptautinių santykių ir politikos mokslų instituto auklètiniai. VSD iki šiol kviečia dirbti aukštaji išsilavinimą turinčius jaunus žmones, kuriuos ketina išugdyti tikrais žvalgais pačioje tarnyboje. VSD darbuotojai - jauni. Vidutinis VSD darbuotojų amžius - 30 metų $^{54}$. Panaši situacija ir AOTD. Todèl patirties trūkumas dar ilgai išliks vienu iš žvalgybos tarnybų veiklą ribojančių veiksnių.

\section{3. Žvalgybos ciklas Lietuvoje}

Visos žvalgybos tarnybos kasdieniniame darbe naudoja penkių žingsnių darbo procesą, kuris vadinasi žvalgybos ciklu. Žvalgybos ciklas nurodo kam reikalinga tam tikra informacija, kaip atsiranda žvalgybos produktas. Svarbiausios šio ciklo dalys yra šios:

- reikalavimu nustatymas. Šiame etape nustatomos sritys ir problemos, kurioms sprendimu prièméjai ir žvalgybos bendruomenè nusprendžia skirti didžiausią dėmesį. Prieš priimdamos sprendimą skirti išteklius tam tikrai krypčiai, žvalgybos tarnybos įvertina tai, ką jos jau žino toje srityje ir ką dar reikia sužinoti. Jos bando nustatyti būdus, kuriais bus renkama reikalinga informacija;

\footnotetext{
${ }^{54}$ VSD bandys atsikratyti jiems nebūdingu funkciju, 200601 30, http://www.sekunde.lt/content. $\mathrm{php} ? \mathrm{p}=$ read\&tid $=27947$.
} 
- rinkimas. Šiame etape slaptais ir atvirais metodais yra renkama informacija. Rinkimo būdų yra labai įvairių, nuo atvirų šaltinių iki palydovinių nuotraukų;

- aiškinimas. Surinkta informacija prieš patekdama analitikams ir sprendimu prièmejjams turi būti interpretuojama (išaiškinama). Tai gali būti teksto vertimas, iššifravimas, nuotraukos išaiškinimas ir pan.;

- analizé ir produkcijos parengimas. Šiame etape žvalgybos tarnybos bando surinktą ir apdorotą informaciją susisteminti, rasti tarpusavio priklausomybę ir rasti atsakymus i pateiktus klausimus. Analitikai turi paaiškinti, kas vyksta, kodèl vyksta, kas atsitiks vėliau ir kaip tai atsilieps šalies interesams;

- platinimas. Žvalgybos tarnybos išanalizuotą informaciją sudeda į pažymas, kurios keliauja tiems sprendimų priemejjams (vartotojams), kurie jų užprašè. Jei sprendimų prièmejjas nepatenkintas atsakymu, jis gali paprašyti daugiau informacijos. Taip ciklas prasideda iš naujo.

Lowenthalis prideda dar dvi žvalgybos ciklo dalis: priẻmimas ir gricžtamasis ryšys. Jo nuomone, sprendimu priemejjai negali automatiškai "suvirškinti“ žvalgybos produkcijos. Žmonès žvalgybinę informaciją priima skirtingai, todèl jų veiksmai, net gavus tą pačią informaciją, gali skirtis. Be to, sprendimų prièmëjai turètu pasakyti žvalgybos tarnyboms, ar jiems tinka teikiama produkcija ir kaip žvalgybos tarnybos galètų geriau reaguoti i juc poreikius.

Šiuolaikiniame pasaulyje žvalgybos profesionalai studijuoja žvalgybos ciklą kaip tam tikrą modeli, kuris aprašo žvalgybos tarnybų darbą. Tai nèra ypatingai griežtas modelis, nes ne visada žvalgybinė informacija yra rengiama tokiu būdu. Arturas Hulnickas pastebėjo, kad tikrovëje praktika dažnai skiriasi nuo teorijos: sprendimų priemëjai retai nustato reikalavimus. Rinkimas ir analizė turètų sekti vienas kitą, tačiau tikrovèje dažnai vyksta vienu metu. Galiausiai sprendimu prièmëjai retai sulaukia žvalgybinès informacijos prieš priimdami sprendimus. Politikai dažniausiai laukia pranešimų, kurie remia ju politiką, o ne suteikia papildomos informacijos tam tikru klausimu ${ }^{55}$. Be kritikos kol kas geresnis modelis nèra sugalvotas, todèl žvalgybos ciklas lieka svarbia dalimi, kaip rengiama ir pristatoma informacija sprendimu prièmejams.

\subsection{Reikalavimų nustatymas}

Reikalavimų nustatymas yra pirmas svarbus žingsnis žvalgybos cikle. Reikalavimai atsiranda iš valstybès nacionalinio saugumo politikos ir nacionalinių interesų. Kartais jie būna aiškiai suformuluoti dokumentuose, pavyzdžiui, nacionalinio saugumo strategijose, tačiau dažniausiai juos diktuoja svarbiausieji įvykiai. Sprendimų priemëjai dažniausiai reikalauja specifiškai

\footnotetext{
${ }^{55}$ Hulnick A. S., What's Wrong with the Intelligence Cycle, Intelligence and National Security, (6) 216, 2006, p. 959-960.
} 
jiems pritaikytos žvalgybinės informacijos, kuri įvertintų dabartiniu įvykiu reikšmę, pasekmes, rizikos faktorius ir galbūt ateities prognozes. Žvalgybos bendruomenè dažniausiai turi pakankamai ekspertų atsakyti į šiuos poreikius, todèl jai yra adresuojami paklausimai ${ }^{56}$.

Ankstesniuose skyriuose jau buvo minèta, kad Lietuvoje nèra institucijos, kuri nustatytų reikalavimus žvalgybos institucijoms. Prezidento, Ministro pirmininko ir Užsienio reikalų ministro nedidelès galimybės dalyvauti žvalgybos procese leidžia Lietuvos žvalgybos tarnyboms dirbti pačioms - t. y. jos pačios sau formuluoja užduotis, renka informaciją, ją analizuoja ir netgi ją vertina. VSD vadovas yra atvirai pripažinęs, kad:

„Problema ... kuri Lietuvoje neišspręsta, yra susijusi su užduočių formulavimu specialiosioms tarnyboms įskaitant VSD. [...] Šiandien Lietuvoje nèra kam formuluoti užduočiu specialiosioms tarnyboms, nepasitariama, kokia kryptimi važiuojame, ką tiriame, pietuose, šiaurèje, ką darome. Valstybëje turi būti sukurtas mechanizmas ir ne žvalgybos ar kažkas kitas turi prisiimti atsakomybę dèl to, kad tyrè tą ar kitą, o tai yra politiniai sprendimai, kuria kryptimi mes ką darome. Jie turi būti priimti, dèl to turi būti susitarta ir tuomet veikiama ${ }^{57}$.

Panaši problema egzistuoja ir Krašto apsaugos ministerijoje - nors ministras ir formaliai nustato prioritetus ir užduotis žvalgybai, tačiau tikrovëje jis neturi personalo, kuris jam patartų, parengtų medžiagą žvalgybinės informacijos rinkimo klausimais. Tokiu atveju, žvalgybos tarnybos tampa priklausomos nuo ministro asmenybės. Jei pastarajam nereikia žvalgybinės informacijos arba pateikiama informacija prieštarauja jo politikai (kurios jis nenori girdèti), žvalgybos tarnybos paliekamos dirbti pačios sau.

Egzistuoja ir kita medalio puse - patyrę politikai ir ar ju patarejjai, net ir noredami, ne visada sugeba užduoti reikiamus klausimus ir suformuluoti reikalavimus. Todèl žvalgybos tarnybos priverstos domėtis įvykiais plačiau. Kaip pastebejjo Hulnickas, nors vartotojai kartais pasako, kokios informacijos jiems reikès, tačiau dažniausiai jie tikisi, kad pačios žvalgybos tarnybos numatys ju poreikius ir įspès apie būsimas problemas ${ }^{58}$. Politikai mégsta skirti dėmesį kasdieninėms problemoms, o ilgalaikès prognozės dažniausiai lieka už jų dèmesio centro. Žvalgybos tarnybos retai gauna nurodymus daryti ilgalaikę analizę.

Dažnai žvalgybos tarnybų analitikai iš turimų duomenų gali pamatyti kylančią problemą, apie kurią politikai net nenujaučia. Dėl to aiškus žvalgybos tarnybų veiklos apribojimas tik aiškiai suformuluotomis užduotimis būtų gana nelogiškas. Malakauskas laidoje „Be pykčio“ gana atvirai pareiškè, kad politikai neturi laiko formuoti užduotis: „Jeigu aš sèdèsiu ir lauksiu kol suformuota užduotis ir po to užduotis bus suformuluota, laivą jau pasukti jau bus

\footnotetext{
${ }^{56}$ Lowenthal,ten pat, p. 57.

${ }^{57}$ Seimo nutarimo „Dèl pritarimo paskirti P. Malakauską Lietuvos Respublikos valstybės saugumo departamento generaliniu direktoriumi“" projektas Nr. XP-2268 (pateikimas) Trisdešimt septintasis (299) posèdis, 20070524.

${ }^{58}$ Hulnick, ten pat, p. 959-960.
} 
per vèlu ${ }^{59 “}$. Todèl VSD turi tapti aktyvia tarnyba, kuri imtųsi priemonių iki pasireiškiant pasekmėms:

„Jeigu specialioji tarnyba, konkrečiai, žvalgyba lauks šių užduočių, irgi nieko nebus, nes negalima gerai suformuluoti užduoties, neturint geros informacijos. Viena iš pagrindinių žvalgybos užduočių ir yra laiku teikti sprendimų prièmëjams informaciją, kad jie galètu tas kryptis suformuluoti. Pasaulio patirtis tokia, kad jeigu to nedarome, tai po to, kai jau problema arba grèsmè išaiškejja, būna per vẻlu suorientuoti tuos žvalgybinius arba specialiuosius pajëgumus į tą kryptít ${ }^{60}$.

Su panašia dilema susiduria ne tik Lietuvos, bet ir kitų šalių žvalgybos tarnybos. Vienintelis jos sprendimo būdus - glaudus, bet ne pernelyg intymus, žvalgu ir politikų bendradarbiavimas. Lietuvoje tai reikštų aktyvesnį politikų ir ekspertu dalyvavima, nustatant žvalgybos reikalavimus, o žvalgybų tarnyboms - geresnį politiku pageidavimų supratimą ir savo produkcijos pristatymą.

\subsection{Rinkimas}

Teoriškai informacijos rinkimo poreikiai kyla iš reikalavimų. Kai reikalavimai žinomi ir prioritetai nustatyti, prasideda antras žvalgybos ciklo etapas - rinkimas. Atsakyti į žvalgybai užduotus klausimas naudojami skirtingi informacijos rinkimo metodai, kurie dažnai papildo vienas kitą. Kadangi informacijos rinkimas reikalauja daug resursu, žvalgybos tarnybos turi iš anksto nuspręsti koks būtent informacijos rinkimų būdas geriausiai atsakys į keliamus klausimus ir paskirstyti prioritetus. Pavyzdžiui, palydovinė nuotrauka mažai ką gali pasakyti apie kibernetines atakas, tačiau gali tiksliai parodyti karinių vienetų išsidèstymą. Kibernetiniu atakų atvejų signalų žvalgyba būtų svarbiausias informacijos rinkimo būdas ${ }^{61}$.

Rinkimo metodai yra tokie svarbūs, kad dauguma žvalgybos analitikų yra linkę žvalgybinę informaciją skirstyti pagal tai, kokiu būdu ji buvo surinkta. Pagal Muller-Wille šis skirstymas yra logiškas, nes kiekvienam reikalingam informacijos tipui naudojamas skirtingas rinkimo metodas. Dažniausiai išskiriami šie rinkimo metodai ${ }^{62}$ :

- Signalų žvalgybos (SIGINT) informaciją gaunama iš ryšių pasiklausymo (COMINT) ir kitų elektroninių (ELINT) spinduliavimų;

- Atvaizdų žvalginè informacija (IMINT). Žvalgybinè informacija gaunama iš atvaizdų renkamų fotografiju, radaru, elektro-optiniu, infraraudonuju, terminių ir multispektriniu sensorių pagalba;

- Žmogiškoji žvalgyba(HUMINT). Žvalgybinè informacija gaunama iš žmonių, vykdant agentūrinę veiklą ir kitais metodais;

\footnotetext{
${ }^{59}$ LTV laida „Be pykčio“, 2007 m. spalio 9 d.

${ }^{60}$ Seimo nutarimo „Dèl pritarimo paskirti P. Malakauską Lietuvos Respublikos valstybès saugumo departamento generaliniu direktoriumi“ projektas Nr. XP-2268 (pateikimas) Trisdešimt septintasis (299) posėdis, $2007 \mathrm{~m}$. gegužès $24 \mathrm{~d}$.

${ }^{61}$ Lowenthal, ten pat, p. 59.

${ }^{62}$ NATO Bendroji žvalgybos, kontržvalgybos ir saugumo doktrina, AJP 2.0, p. 1-6.
} 
- Atvirų šaltinių žvalgybinė informacija (OSINT). Žvalgybinė informacija gaunama iš visiems pasiekiamų šaltiniu, radijo, televizijos, laikraščiu, knygų.

Kiekvienas rinkimo metodas leidžia vis skirtingai pažvelgti į tam tikrą problemą. Kai analizè vykdoma, pasitelkiant visą surinktą informaciją, rinkimo disciplinos gali pateikti viena kitai užuominas arba net raktą į teisingą atsakymą. Tai vadinama visu rūšių žvalgyba (angl. all-source intelligence arba fusion intelligence $)^{63}$.

Lietuvos žvalgybos tarnybos gali rinkti informaciją visais įmanomais būdais, tačiau daugelyje sričių Lietuva turi remtis sajungininkų teikiama informacija. Informacijos rinkimą ir panaudojimą riboja labai nedideli žvalgybos tarnybų biudžetai ir profesionalus personalo stoka. Mažas tarnybų dydis ir finansinès galimybės iš anksto leidžia teigti, kad tam tikrose srityse Lietuva neturi savarankiškų informacijos rinkimo, pavyzdžiui, per palydovus, galimybių.

- SIGINT turi senas tradicijas - Lietuvoje prieš karą telefoninių pokalbiu Žvalgybos skyrius pradëjo klausytis dar $1921 \mathrm{~m} .{ }^{64}$ Apie šiuolaikines SIGINT galimybes sunku spręsti, nors Visockas ir Kaminskas mini AOTD radijo žvalgybos skyrių, kuris disponuoja specialiaja aparatūra, reikalinga SIGINT funkcijoms atlikti ${ }^{65}$.

- IMINT yra labai platus informacijos šaltinis, kuris remiasi tiek sajungininku teikiama informacija, tiek šaltiniais, atvirai pasiekiamais. Dalis IMINT informacijos yra susieta su HUMINT veikla, apie kurią yra mažai žinoma.

- HUMINT yra slapčiausia žvalgybos tarnybų sritis, apie kurią viešos informacijos beveik nèra. Galima daryti prielaidą, kad Lietuvos teritorijoje žvalgybos tarnybos turi tam tikrus HUMINT pajėgumus, tačiau finansinės ir žmogiškosios aplinkybès turètų riboti galimybes vykdyti agentūrinį darbą užsienio šalyse. Tiesa, kartais Rusija apkaltina Lietuvą vykdant tam tikras operacijas jos teritorijoje. Pavyzdžiui, 2008 m. pradžioje Rusijos Federalinès saugumo tarnybos atstovai žiniasklaidai pranešè, jog „per parengtinį tyrimą ir teismo procesą nustatyta, kad Lietuvos žvalgybos užverbuotas ir jos užduotis vykdęs Vasilijus Chitriukas ilgą laiką už piniginį atlyginimą rinko ir perdavinèjo užsienio specialiosios tarnybos darbuotojui įvairią informaciją apie Rusijos ginkluotuju pajègų dalis ir junginius“"66. Tokie pareiškimai gali būti tiek tikros situacijos aprašymas, tiek propagandinis triukas.

- OSINT turètų būti stipriausia žvalgybos tarnybų veiklos sritis. Ji yra pigiausia (nors anaiptol ne pigi), o jos interpretavimas reikalauja geru analitiku, kuriuos galima paruošti, remiantis sąjungininkų pagalba tiek Lietuvoje, tiek už jos ribų.

\footnotetext{
${ }^{63}$ Lowenthal, ten pat, p. 70.

${ }^{64}$ Anušauskas, ten pat, p. 56.

${ }^{65}$ Visockas, Kaminskas, ten pat, p. 109-110.

${ }^{66}$ „Kaliningrade - tariamos Lietuvos žvalgybos byla“, Vakaru ekspresas,

20080117 d., http://www.ve.lt/?data=2008-01-17\&id=1200586047\&page=print.
} 


\subsection{Aiškinimas}

Rinkimo rezultatas yra neapdirbta informacija arba duomenys, bet ne žvalgybos informacija. Surinkta informacija turi būti interpretuota ir išaiškinta. Šiame etape atitinkamai paruošti specialistai neapdirbtus duomenis paverčia į analitikams suprantamą informaciją. Tai reiškia signalų iššifravimą, fotografiju interpretavimą, vertimą iš kitu kalbų ir t. t. Neturètų stebinti, kad interpretavimas reikalauja didžiulių žmoniškuju pastangų. Todèl ne visa surinkta informacija atsiduria ant analitikų stalų, daugybè jos niekada nèra panaudojama, o didžiulès lèšos skirtos jai surinkti išleidžiamos veltui.

Mažoms valstybėms informacijos išaiškinimas gali kelti didelių rūpesčių. Jos privalo turèti kompetentingu specialistu, kurie sugebėtu apdoroti informaciją surinktą ne tik savarankiškai, bet ir gautą iš sajungininku. Neturint tam tikrų techninių priemoniu, pavyzdžiui, palydovu, sunku išugdyti gerus palydovinių nuotraukų interpretavimo specialistus. Tokią pagalbą gali suteikti tik užsienio partneriai arba užsienyje mokyti Lietuvos pareigūnai. Tačiau kai kuriose srityse Lietuvos pajegumai yra gerai vertinami.

Informacijos apdorojimą sunkinti ir kalbos barjerai. Kaip pripažino VSD terorizmo valdybos ekspertas R.Valančius, situacija dèl užsienio kalbu yra sunki, tačiau padètis gerëja: „,specialistai vis daugiau mokosi arabu, turku $\mathrm{kalbu}^{\prime \prime}{ }^{\prime 67}$. Tokių specialistų paklausa ypač didelè tarptautinėse operacijose, kur reikia bendrauti su vietiniais gyventojais ir užsiimti taktiniu HUMINT. Stiprioji Lietuvos pusé - geras mūsų rytinių kaimynų kalbų mokejjimas, kuris, Rusijai vis labiau plečiant įtaką i posovietinę erdvę, tampa vis didesniu Lietuvos tarnybu pranašumu, netgi savotiška specializacija.

\subsection{Analizè}

Reikalavimu nustatymas, informacijos rinkimas ir jos interpretavimas neturi jokios prasmès, jei vẻliau surinkta informacija neatsiduria analitiku rankose. Jie yra tam tikrų sričių ekspertai, kurie sukuria produkciją, vẻliau pasieksiančią sprendimu prièméjus. Analizė yra intelektualinė veikla, kurios metu atsiranda produktas - įvertinimas, prognozè ar dabartinès padèties nusakymas. Pati analizė dažnai skirstoma į dvi didelės grupes: kasdieninė analizė didžiausią dėmesį skiria įvykiams, kurie dominuoja politikų darbotvarkëje ir reikalauja greitai reaguoti. Ilgalaikès analizės objektas - kryptys ir tendencijos, kurių dabar galbūt nėra politikų darbotvarkëje, tačiau bus svarbios nacionaliniams interesams. Tarp šių dviejų darbo krypčių visada egzistuoja tam tikra itampa. Lowenthalio nuomone, darbo paskirstymo prasme, abi sritys turi gauti vienodą dèmesį ${ }^{68}$.

\footnotetext{
${ }^{67}$ R. Valančius, „Terorizmo prevencija“, Seminaras „Šiandienis terorizmas ir savižudžių terorizmas“, LKA, 2006 m. gegužès $19 \mathrm{~d}$.

${ }^{68}$ Lowethal, ten pat, p. 61.
} 
Stengdamiesi atsakyti ị esamus reikalavimus, analitikai stengiasi susisteminti įvairiais būdais surinktą informaciją. Analitikas prideda savo žinias, patirtị ir tam tikrais atvejais savo nuovoką, kaip pakryps būsimi įvykiai. Geras analitikas nèra valdomas tik "techninès" informacijos - siekdamas suprasti aplinkini pasauli, jis turi pasikliauti bendra nuovoka ir sveiku protu, stengtis nujausti įvykių tendencijas. Žvalgyba, pirma, analizuoja žmonių sprendimus, kurie ne visada yra racionalūs ir lengvai nuspejjami, todèl analitikas privalo atsižvelgti ị žmogiškajị faktorių ar suprasti kultūrinę oponentų aplinką.

Svarbu pastebèti, kad žvalgybos tarnybos rengia ilgalaikes ir trumpalaikes prognozes, naudodamos tuos pačius metodus kaip socialiniai mokslai (diskurso analizė, lyginamasis metodas, statistinè analizè ar pan.). Todèl, kaip pastebi Schulskis ir Schmitas, žvalgybos analitiko vertinimas nèra kažkuo labai išskirtinis ar teisingesnis nei kitų atlikta analizė, išskyrus tuos atvejus, kai žvalgybos tarnybos turi tam tikros slaptos informacijos, kuri leidžia įvykius interpretuoti kitaip. Pavyzdžiui, žvalgybos tarnybos atlikta ilgalaikẻ Rusijos ekonominès plètros analizė nėra nẻ kuo geresnè nei rimto Vakaru Europos ar JAV universiteto pateikta nuomonė šiuo klausimu, nebent žvalgybos tarnyba turi specifinius duomenis, iš esmès keičiančius prognozuojamu ivvykių Rusijoje scenarijus. Kitas pavyzdys - diplomatinės ataskaitos apie politinę padėtį tam tikroje šalyje gali būti ypatingai svarbūs sprendimu prièméjui, nes diplomatas, kuris reziduojamoje šalyje gali bendrauti su svarbiais politikais, gali geriau suprasti įvykius šalyje nei žvalgybos analitikas ${ }^{69}$.

Nenuostabu, kad buvęs JAV gynybos sekretorius Donaldas Rumsfeldas spaudos konferencijoje yra pareiškęs, kad ,,jeigu atidžiau pagalvotume, tai žvalgyba neteikia nepajudinamų ir tvirtų išvadų. Ką ji pateikia, tai spekuliacijos, analizè, tikimybès, galimybès, vertinimai. Geriausi spëjimai ${ }^{70 "}$. Dèl žvalgybinès informacijos nepatikimumo (ypač ilgalaikių prognozių) sprendimu prièméjai turi visą teisę ją atmesti ar ignoruoti. Juk vẻliau jie bus atsakingi už savo sprendimų rezultatus, o ne žvalgybos bendruomenè.

Be ilgalaikès analizès trūkumu, neturint brangiai kainuojančių techniniu informacijos rinkimų pajėgumu, Lietuvos dèmesys turètų būti kreipiamas būtent $\mathfrak{i}$ analizès pajègumu stiprinimą, gebèjimą interpretuoti ir suprasti iš atvirų šaltinių ar sajungininkų gaunamą informaciją. Investicija į analizę - tai investiciją į žmonių kompetencijos stiprinimą, „protų pritraukimą“. Lietuvos žvalgybos tarnybų analitinių padalinių stiprybė yra geras regiono istorijos, tradicijų, kalbų žinojimas, kaimynų charakterio ir darbo metodų supratimas. Apie kai kuriuos įvykius mažu valstybių turima informacija dažnai būna tikslesnè net nei didžiuju pasaulio valstybių žvalgybos tarnybų. Pavyzdžiui, Lietuva gali nedaug nusimanyti apie situaciją Čade, tačiau Kaliningrado srities problemos yra aiškiai suprantamos ir suvokiamos Lietuvoje.

Reikia pripažinti, kol kas Lietuvoje net ir turimi analizės ar informacijos

\footnotetext{
${ }^{69}$ Shulski, ten pat, p. 39.

${ }^{70}$ Jack D., ,Intelligence Analysts and Policymakers: Benefits and Dangers of Tensions in the Relationship", Intelligence and National Security, (6)21, 2006, p. 1001.
} 
rinkimo pajėgumai nėra iki galo išnaudojami. Pavyzdžiui, Lietuvai sprendžiant, ar verta vadovauti Afganistano Goro provincijos atstatymo grupei, į žvalgomaji skrydį nebuvo paimtas nei vienas AOTD ar VSD specialistas. Todèl pasirengimas operacijai vyko beveik neatsižvelgiant į vietos tradicijas, ju kultūrą, valdymo sistemą, psichologinę aplinką ar kitus ne karinius faktorius. Tokiais atvejais žvalgybos bendruomenė yra demoralizuojama, nes aiškiai parodoma, kad jų turimos žinios nebus naudojamos.

\subsection{Platinimas}

Platinimas - tai žvalgybos produkcijos pristatymas vartotojams, t. y. sprendimu prièmëjams. Informacija gali būti teikiama įvairiais būdais - nuo žvalgybos pažymų apie besikeičiančią situaciją iki ruošiamų didelių studiju baigiantis metams ${ }^{71}$. Kasdieninė žvalgyba yra ypač svarbi sudètingose konsultacijose arba derybose, kur kitų šaliu pozicijos išankstinis žinojimas gali pokalbiu rezultatus pakreipti visai kita linkme. O gynybos planuotojams svarbiausia yra ilgalaikè prognozè, nes ginkluotosios pajėgos kuriamas pagal ateities grèsmių scenarijus.

Valstybės biurokratinè kultūra ir specifiniai informacijos poreikiai apibrèžia kur ir kaip bus platinama žvalgybinè informacija. Valstybėse žvalgybinė informacija yra pateikiama aukščiausiems sprendimų priemėjams - prezidentams, ministrams pirmininkams, ministrams ir jų padejejejams. Pavyzdžiui, JAV žvalgybos bendruomenè platina šiuos produktus:

- Prezidento kasdieninė santrauka (angl. President's Daily Brief) - kiekvieną rytą JAV prezidentui teikiama svarbiausių naujienų išklotine;;

- Vyriausiuju pareigūnu žvalgybos santrauka (angl. Senior Executive Intelligence Brief) yra rengiama CŽV, o jos adresatų sąrašas yra gerokai platesnis;

- Karinès žvalgybos santrauka (angl. The Military Intelligence Digest) yra rengiama Gynybos žvalgybos agentūros ir sutelkta į karinius klausimus, nors tam tikrais atvejais persidengia su Vyriausiujų pareigūnų žvalgybos santrauka;

- Nacionaliniai žvalgybos vertinimai (angl. National Intelligence Estimates) tai suderinta žvalgybos bendruomenés nuomonè, pateikianti ilgalaikes tam tikrų sričiuc prognozes. Kartais jų dalys gali būti paskelbtos viešai.

- Kiti sprendimų prieméjai ir jų štabai gauna labiau jų poreikiams pritaikytą žvalgybos informaciją.

Lietuvoje VSD ir AOTD valdžios institucijoms pateikia pažymas. Pažyma tai analitinis produktas, kuriame pateikiamas tam tikros situacijos vertinimas žvalgybos tarnybos akimis. Pažyma nèra teisinis dokumentas, jis neturi jokio juridinio statuso. Dar daugiau - žvalgybos tarnybų vertinimas nebūtinai yra teisingas, dèl

${ }^{71}$ Lowenthal, ten pat, p. 62. 
įvairiausių priežasčių analitikai gali klysti arba būti suklaidinti. Ypač tolimesniu įvykiu prognozės yra paremtos geriausiu spejjimu ir nuojauta, kuri ne visada pasitvirtina.

Visa parengta žvalgybinè informacija turi būti laiku ir suprantama forma pateikta sprendimų priemėjams ir rengëjams, kurie sprendžia, kaip ją panaudoti. Lietuvoje nèra sukurta informacijos pateikimo sistema, o pats procesas kol kas yra gana chaotiškas.

2 lentelè. Lietuvos žvalgybos tarnybų rengiami produktai

\begin{tabular}{|c|c|c|}
\hline & VSD & AOTD \\
\hline Ilgalaikè & Nèra & $\begin{array}{l}\text { Metinis grėsmių žvalgybi- } \\
\text { nis vertinimas }\end{array}$ \\
\hline $\begin{array}{l}\text { Vidutinès } \\
\text { trukmès }\end{array}$ & $\begin{array}{l}\text { Informaciniai pranešimai - } \\
\text { svarbiausių įvykių ir procesu } \\
\text { vertinimas (keletą kartų per } \\
\text { savaitę) }\end{array}$ & $\begin{array}{l}\text { Kasdieninių ivvykiu vertini- } \\
\text { mas (nereguliariai) }\end{array}$ \\
\hline \multirow[t]{2}{*}{ Trumpalaikè } & $\begin{array}{l}\text { Informacinės pažymos kasdie- } \\
\text { niniams įvykiams vertinti. }\end{array}$ & $\begin{array}{l}\text { Situacijos operacijose verti- } \\
\text { nimas (kartą per savaitę) }\end{array}$ \\
\hline & & $\begin{array}{l}\text { Vidinis kariuomenės verti- } \\
\text { nimas }\end{array}$ \\
\hline
\end{tabular}

Lietuvos žvalgybos tarnybų produkcijos pateikimo tvarka nedaug skiriasi nuo užsienio šaliu tarnybų produkcijos pateikimo tvarkos, nors pora išskirtinių savybių iš karto krenta į akis:

- VSD nerengia jokių ilgalaikes perspektyvas numatančių dokumentų. Tokia situacija gali būti paaiškinama tiek užduoties nebuvimu (niekas nepaprašè), tiek tuo, kad, dèl VSD turimų teisėsauginės funkciju, jos analitikų veikla yra nukreipta į operatyvinès veiklos palaikymą, o ne i ilgalaikių planų ar strategijų rengimą;

- Nèra bendru VSD ir AOTD produktų, jungtinis žvalgybinis vertinimas Lietuvoje neegzistuoja. Sričių, kur toks vertinimas būtų naudingas yra daugybė, jau nuo procesų Rusijoje stebèjimu, iki Lietuvos dalyvavimo operacijose vertinimu;

- Žvalgybos tarnybų daroma analizè niekaip nesusijusi su strateginiais Lietuvos dokumentais. Pavyzdžiui, Lietuvos nacionalinio saugumo strategija ar kitos strategijos nėra susijusios su žvalgybos tarnybų veikla;

- Prezidentui ir Premjerui nedaroma Vakaru šalyse iprasta Kasdieninė žvalgybos santrauka, kuria reziumuojami iš įvairiausių šaltinių surenkami pastarujuc dienų įvykiai.

Produktų pateikimo trūkumai reiškia daugybę neišnaudotų galimybių, kurios nepatenkina žvalgybinès produkcijos vartotoju poreikių. Žvalgybos tarnybos turi ne tik surinkti ir išanalizuoti turimą informaciją, bet ir tinkamai ją paskleisti politikams, o galbūt net siūlyti sprendimų variantus. Kitaip visas ju 
darbas yra bevertis. Neatsitiktinai buvęs VSD vadovas Laurinkus, kalbėdamas apie VGT veiklą, akcentavo, kad:

„valstybės veiklos planavimo procese turi būti daug labiau išnaudojamos VSD informacijos rinkimo, analizès ir strateginio planavimo galimybės. [...] Negaliu suprasti, kodèl ten, kurs svarstomi strateginiai valstybès gyvenimo klausimai, nedalyvauja Saugumo departamento atstovai? Stengiausi keisti tokị Vyriausybės vadovų požiūrị i departamentą, tik kad tos Vyriausybès labai dažnai keičiasi... ${ }^{72}$

Šiame Laurinkaus pasisakyme galima įžvelgti svarbesnę - politikų ir žvalgybos - santykio problemą. Žvalgybos tarnybos nèra tik informacijos i politiku paklausimus tiekimo institucijos. Žvalgyba turi pateikti platų ir išsamų grèsmių bei iššūkių valstybei aprašymą, teikiant politikams svarbią informaciją, kurios jie net nesugalvotu paprašyti arba nenorètų matyti ant savo stalo. Žvalgybos tarnybu atskyrimas nuo strategijos formavimo arba, anot Laurinkaus, „valstybès veiklos planavimo proceso" leidžia politikams išvengti ir nepriimti nepageidaujamos arba net skaudžios informacijos.

Dabartinio VSD direktoriaus Malakausko nuomone, žvalgai turi eiti toliau - jie ne tik teikia savo įvykių interpretaciją, bet siūlo sprendimus - pateikia galimus variantus. Tokiu būdu jie iš dalies tampa politikos dalyviais. Jo nuomone, VSD turi tapti sprendimu paramos institucija, padedanti priimti sprendimus, o ne tik informacine tarnyba ${ }^{73}$.

Toks aktyvus žvalgo (analitiko) dalyvavimas, priimant sprendimą, gali turèti blogu pasekmių žvalgybos efektyvumui ir tapti žvalgybinės informacijos iškraipymo priežastimi. Pagrindinè problema yra galimas žvalgų suinteresuotumas jo rekomenduoto sprendimo igyvendinimu. Zvalgybos tarnybos, rekomendavusios tam tikrą sprendimą, jausis morališkai įsipareigojusios pasiekti, kad ju rekomendacija pasirodytų teisinga. Jos gali pradèti kištis į vykdomosios valdžios veiksmus, skirtus jam igyvendinti ir taip peržengti savo kompetencijos ribas.

Sveikam ryšiui reikalingas sveikas balansas, kuris remtųsi politiku supratimu apie žvalgybos tarnybų specifika, ir žvalgu supratimu, kad dèl daugybės aplinkybiu politiniai sprendimai nebūtinai gali remtis jų teikiamomis rekomendacijomis. Todèl būtent vienas iš didžiausių iššūkių yra sukurti deramus saugiklius, saugančius žvalgybą nuo politizavimo, tačiau leidžiančius žvalgybinės informacijos leidejui ir politikos formuotojui sąveikauti ${ }^{74}$.

\subsection{Prièmimas}

Sprendimų priemėjams pateikta informacija nẻra priimama automatiškai, ji yra interpretuojama, ir tik tada pritaikoma praktiškai. Sprendimu priemėjai nèra automatai, kurie nuosekliai seka žvalgybos tarnybų rekomendacijomis,

\footnotetext{
${ }^{72}$ Bačiulis A., „Lietuva dar neišmoko naudotis savo žvalgyba (pokalbis su VSD vadovu M. Laurinkumi)“, Veidas, 34, 20020822.

${ }^{73}$ LTV laida „Be pykčio“.

${ }^{74}$ Bagdonas, 2006, p. 12.
} 
jie nebūtinai bus linkę pateiktą informaciją panaudoti taip, kaip buvo sumanę žvalgybos tarnybų darbuotojai. Hulnickas pastebejjo, kad aukščiausi pareigūnai dažnai turi tik 10-15 minučių priimti žvalgybos informaciją. İvairūs tyrimai rodo, kad būtent tiek laiko sprendimu prièmëjai gali skirti tokio pobūdžio veiklai, todèl nenuostabu, kad pats paklausiausias produktas yra kasdieninè žvalgyba ${ }^{75}$.

Norėdamos pritraukti politikų dèmesi žvalgybos tarnybos kartais persistengia ir perkrauna valstybès vadovus labai įslaptinta "sensacinga" informacija. Žvalgyba kasdien gauna informaciją apie laukiančius pavojus, tačiau dažniausiai grèsmingai atrodantys įspejjimai būna neteisingi arba pernelyg abstraktūs ${ }^{76}$. Be to, politikai gali greitai priprasti prie nuolat skambančio pavojaus varpo ir pradèti ji ignoruoti. Pavyzdžiui, $2001 \mathrm{~m}$. liepos mèn. CŽV direktorius George Tenetas pateikè JAV administracijai tiek daug informacijos apie įvairiose srityse gresiančius pavojus, kad kai kurie administracijos pareigūnai tiesiog nuo jos pavargo ${ }^{77}$. Šioje situacijoje nenuostabu, kad įspejjimas apie galimus teroristinius aktus buvo praleistas be reikiamo dėmesio.

Iki šiol Lietuvos politikai nerodė didelio susidomėjimo žvalgybos tarnybų kasdienine veikla. Dar 2002 m. Laurinkus pripažino, kad:

su [Prezidentūra] mūsų bendradarbiavimas labai glaudus - kartą per savaitę ar aš pats, ar mano igaliotas asmuo teikia informaciją Prezidentui. Be to, iš Prezidentūros mes nuolat gauname paklausimų. Tuo tarpu su Vyriausybe mūsų bendradarbiavimas kažkoks fragmentiškas. Pats patyriau, kad su kiekvienu nauju premjeru bendradarbiauti pradedama tarsi nuo nulio. Man jie užduoda tokių klausimų, kad susidaro įspūdis, jog žmogus pirmą kartą išgirsta, ką VSD gali ir sugeba. Algirdas Brazauskas - bene vienintelè išimtis. Tiesa, Andrius Kubilius irgi daugiau darbo mums užduodavo, tačiau jis labai trumpai buvo premjeras ${ }^{78}$.

Sprendimų priemėju patarejjai ir planuotojai turi daugiau laiko priimti žvalgybinę analizę, todèl jų sugebejjimas ją suprasti ir panaudoti yra kompetencijos ir patirties klausimas. Būtent jie privalo susieti žvalgybos tarnybu teikiamas prognozes su tikrais veiksmais ir ilgalaikiais planais. Žvalgybos tarnybos turi skirti didesnį dèmesį tiems, kurie rengia sprendimus, o ne tiems, kurie juos priima.

\subsection{Grižtamasis ryšys}

Geras žvalgybos tarnybų darbuotojų ir sprendimų priemėjų ryšys padidina žvalgybos darbo efektyvumą. Grižtamasis ryšys yra būtinas tam, kad žvalgybos tarnybos sugebėtu įvertinti savo darbo trūkumus ir pasiekimus,

\footnotetext{
${ }^{75}$ Hulnick, ten pat, p. 965.

${ }^{76}$ Parker C., Stern E., „Bolt from the Blue or Avoidable Failure? Revisiting September 11 and the Origins of Strategic Surprise“, Foreign Policy Analysis, 1, 2005, p. 309.

${ }^{77}$ Parker, Stern, ten pat, p. 311.

${ }^{78}$ Bačiulis, ten pat.
} 
ir pritaikytų žvalgybinės informacijos pateikimą prie sprendimu priëmëju poreikių.

Sprendimų priemeejai turètų pateikti savo nuomonę, ar juos tenkina žvalgybos tarnybos produkcija ir pasakyti savo norus, kokios informacijos ir kada jie norètų gauti. Turètų nutikti taip, kad klausimas dar tebėra aktualus - tai leistų žvalgybos tarnyboms greitai adaptuoti savo veiklą prie naujų poreikių. Tačiau praktikoje toks įvertinimas yra gana retas reiškinys.

Nesugebëjimas vertinti žvalgybos tarnybu produkcijos yra ne tik Lietuvos, bet ir kitų mažu, ypač pokomunistinių, šalių problema. Yra kelios šio reiškinio priežastys:

- pirma, žvalgybos tarnybos nespeja išsiugdytu pakankamai kompetentingo personalo savo pačiu poreikiams patenkinti, todèl politinèms partijoms ar valstybinèms institucijoms rasti patyrusị ir gerai užsirekomendavusį ekspertą, kuris galètų kritiškai įvertinti žvalgybos tarnybu darbą, yra ypač sunku. Žvalgybinès informacijos vartotojai tiesiog nesugeba suformuluoti savo pastabų ir pageidavimu.

- Antra, kol Lietuvoje žvalgybos tarnyboms nèra keliami aiškūs uždaviniai, sprendimu priemejjai negali pateikti vertinimu, kaip žvalgybos tarnybu produkcija atitiko ju poreikius.

\section{Išvados ir rekomendacijos}

Atsikūrusios Lietuvos žvalgybos tarnybos perëjo keletą evoliucijos etapų. Ir nors nuo $1994 \mathrm{~m}$. ju statusas ir pavaldumas beveik nesikeite, jų funkcijos plètėsi, o veikla susilaukdavo vis didesnio visuomenès rezonanso. Galima įvardinti nemažai sėkmės istorijų - sẻkmingas bendradarbiavimas su sajungininkų analogiškomis tarnybomis, analizès pajègumų stiprëjimas, didejjantis piliečių ir politikų susidomëjimas žvalgyba leidžia sukurti palankią aplinką stabiliai žvalgybos tarnybų veiklai.

Be institucinio stabilumo ir daugelio teigiamų poslinkiu, lieka nemažai spręstinų problemų. Lietuvoje dar nepavyko sukurti gerai veikiančio žvalgybos ciklo, kuris užtikrintų renkamos ir analizuojamos informacijos atitikimą sprendimų priemmëju poreikiams. Neaiškus pavaldumas, menkas vartotojų išmanymas apie žvalgybos produkciją, pernelyg artimi politikų ir žvalgų santykiai iki šiol išlieka svarbiomis Lietuvos žvalgybos tarnybu problemomis.

Šiame straipsnyje buvo parodyta, kad egzistuoja nemažai būdu, kaip stiprinti Lietuvos žvalgybos tarnybų veiklą. Galima išskirti pagrindinės tolimesnio darbo kryptis:

- investuoti žmones. Žvalgybos tarnybų darbuotojų kvalifikacijos stiprinimas ir žvalgybinès bendruomenės už žvalgybos tarnybų ribų turètu išlikti svarbiausiu uždaviniu;

- peržiūrèti žvalgybos ciklo igyvendinima. Nors žvalgybos ciklas nėra ide- 
alus darbo modelis, bet jis leidžia logiškai sudèlioti visus žvalgybos tarnybų darbo etapus. Reikalavimų nustatymas, produkcijos pateikimas ir grižtamojo ryšio nebuvimas yra silpniausios ciklo dalys Lietuvoje. Prezidentūroje, Užsienio reikalų ministerijoje ir kitose institucijose turi būti suformuotos patariamosios grupės, kurios dalyvautu, formuluojant reikalavimus žvalgybai ir užtikrinant grịžtamajji ryšį;

- funkciju ir pavaldumo peržiūra. Institucinis Lietuvos modelis nėra ydingas, tačiau dvigubo pavaldomo panaikinimas, žvalgybos ir teisėsaugos atskyrimas, aiškesnis funkcijų suformulavimas palengvintų žvalgybos sistemos funkcionavimą. Šie pakeitimas galètų būti ịgyvendinti, prièmus naują Žvalgybos įstatymo redakciją;

- finansavimo užtikrinimas. Mažas finansavimas iki šiol neleidžia pritraukti pačiu geriausių specialistų ir ypač riboja techninių informacijos galimybių įsigijimą. 